ANNEALING STUDIES ON IRRADIATED TYPE 347 STAINLESS

MASTER

BATTELLE MEMORIAL INSTITUTE 


\section{LEGAL NOTICE}

This report was prepared as an account of Government sponsored work. Neither the United States, nor the Commission, nor any person aeting on behalf of the Commission:

A. Makes any warranty or representation, expressed or implied, with respect to the accuracy, completeness, or usefulness of the information contained in this report, or that the use of any information, apparatus, method, or process disclosed in this report may not infringe privately owned rights; or

B. Assumes any liabilities with respect to the use of, or for damages resulting from the use of any information, apparatus, method, or process disclosed in this report.

As used in the above, "person acting on behalf of the Commission" includes any employee or contractor of the Commission, or employee of such contractor, to the extent that such employee or contractor of the Commission, or employee of such contractor prepares, disseminates, or provides access to, any information pur suant to his employment or contract with the Commission, or his employment with such contractor.

Printed in USA

Price $\$ 1.25$

Available from the Office of Technical Services

U. S. Department of Commerce

Washington 25, D. C. 


\section{DISCLAIMER}

This report was prepared as an account of work sponsored by an agency of the United States Government. Neither the United States Government nor any agency Thereof, nor any of their employees, makes any warranty, express or implied, or assumes any legal liability or responsibility for the accuracy, completeness, or usefulness of any information, apparatus, product, or process disclosed, or represents that its use would not infringe privately owned rights. Reference herein to any specific commercial product, process, or service by trade name, trademark, manufacturer, or otherwise does not necessarily constitute or imply its endorsement, recommendation, or favoring by the United States Government or any agency thereof. The views and opinions of authors expressed herein do not necessarily state or reflect those of the United States Government or any agency thereof. 


\section{DISCLAIMER}

Portions of this document may be illegible in electronic image products. Images are produced from the best available original document. 


\author{
Report No. BMI-1621 \\ UC-25 Metals, Ceramics, \\ and Materials \\ (TID-4500, 19th Ed)
}

Contract No. W-7405-eng-92

ANNEALING STUDIES ON IRRADIATED

TYPE 347 STAINLESS

by

William E. Murr

Frederic R. Shober

March 6, 1963

\author{
BATTELLE MEMORIAL INSTITUTE \\ $505 \mathrm{King}$ Avenue \\ Columbus 1, Ohio
}


$\bullet$

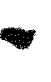

$\nabla$

0. 
TABLE OF CONTENTS

Page

ABSTRACT • • . . . . . . . . . . . . . . . . . . . . . 1

INTRODUCTION

FABRICATION HISTORY OF J-10 PRESSURE TUBE AND GAS JACKET . . . . 2

IN-PILE DESIGN PARAMETERS AND OPERATING HISTORY $\quad . \quad$ • • . . $\quad 3$

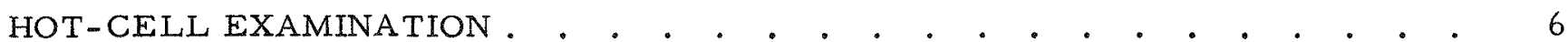

Surface Condition . . . . . . . . . . . . . . . . . 6

Sectioning of J-10 Tubes. . . . . . . . . . . . . . . . . 6

Gamma Scan of Loop Strips . . . . . . . . . . . . . . . . . . . . . . . 6

Dosimetry. . . . . . . . . . . . . . . . . . . . . . . . . . . . . 7

Heat Treatment of Specimen Blanks . . . . . . . . . . . . . . 12

Machining of the Tensile-Test Specimens . . . . . . . . . . . . 12

Tensile-Testing Experimental Procedure . . . . . . . . . . . . 15

Test Results . . . . . . . . . . . . . . . . . . . . . . . 16

Hardness . . . . . . . . . . . . . . . . . . . . . 16

Metallographic Examination . . . • . . . . . . . . . . . . 18

CONCLUSIONS • • . . . . . . . . . . . . . . . . . . . . . . . . . 19

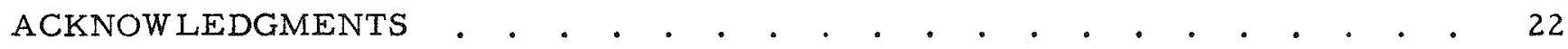

REFERENCES • . . • . . . . . . . . . . . . . . . . . . . . . . . 22

APPENDIX

FRACTURE ZONES OF SPECIMENS TESTED. . . . . . . . . . . . . A-1 


\title{
ANNEALING STUDIES ON IRRADIATED TYPE 347 STAINLESS
}

\author{
William E. Murr and Frederic R. Shober
}

\begin{abstract}
The effects of $1-h r$ anneals at 1000 and $1800 \mathrm{~F}$ on the mechanical properties of Type 347 stainless steel specimens taken from the ETR $1-10$ pressure iube after fast-neutron $(>1 \mathrm{Mev})$ exposures of about $7.1 \times 10^{21} \mathrm{nvt}$ were studied. The pressure tube operated at a maximum temperature of about $750 \mathrm{~F}$ in a stressed condition. Testing was carried out at 75 and $750 \mathrm{~F}$. Uniform elongations were increased from approximately 1 per cent in the asirradiated material to 15 and 25 per cent, respectively, by the 1000 and $1800 \mathrm{~F}$ anneals. The $1000 \mathrm{~F}$ annealing appeared to produce a better combination of mechanical properties. The microstructure of unirradiated, as-irradiated and postirradiation annealed specimens were very similar except for two specimens inadvertently heated above $1800 \mathrm{~F}$ during annealing.
\end{abstract}

\section{INTRODUCTION}

The ETR contains facilities to accommodate test loops which provide special temperature, pressure, and atmosphere conditions for irradiation testing according to specific requirements of the various reactor customers. Such a test loop was recently removed from the $J-10$ position of the ETR after having been in service approximately 17 months. This loop consisted of two basic capsules or tubes, an inner tube containing test specimens in pressurized water and an outer surrounding tube or jacket separated from the inner tube by a helium gas annulus. The outside of the outer tube made contact with reactor process water. This particular J-10 test loop was placed in service in the ETR in October, 1959, and was removed from the ETR on March 16, 1961. During this time the loop was exposed to approximately 222 effective full-power days $(38,800$ megawatt-days) at an estimated computed maximum flux (neutrons with energies $>1 \mathrm{Mev}$ ) of $3.7 \times 10^{14} \mathrm{nv}$. A 36-in.-long section corresponding in length to the active fuel core of the ETR was removed from both inner and outer loop sections and shipped to the Battelle Hot-Cell Facility for postirradiation examination.

The J-10 loop sections were utilized in two individually sponsored programs. The Division of Reactor Development of the AEC funded the preparation, testing, and posttest examination of 18 specimens, including six from the outer gas jacket and 12 from the inner pressure tube. These specimens were all tested in the as-irradiated condition at room temperature or at $750 \mathrm{~F}$. The results of the examinations were presented in BMI-1609. (1) The second program, sponsored by the Westinghouse Electric Corporation, Bettis Atomic Power Laboratory, included the preparation, heat treatment, testing, and posttest examination of 18 additional specimens machined from the $\mathrm{J}-10$ inner pressure tube. The details and results of the examinations performed in the program sponsored by Bettis are presented in this report. The results reported in BMI- 1609 for the tests made on the inner pressure tube and the outer gas jacket are also listed in this report in order to provide a comparison of properties of as-irradiated and annealed tensile specimens.

(1) References appear at end of text. 
The pressure tube was fabricated by Thompson Products (Jet Division) from a forging produced by McInnes Steel Company. The initial billet, which was 6 in. in diameter, was heated to $2250 \mathrm{~F}$ and reduced by forging to $3 \mathrm{in}$. in diameter and air cooled. The forging was then rough machined, stressurelief annealed for $1 \mathrm{hr}$ at $1000 \mathrm{~F}$, and water quenched. The core section of the pressure tube was milled from the billet at this point. Tensile properties of specimens removed from opposite ends of the billet are given in Table 1, along with chemical analyses of the finished billet.

TABLE 1. COMPOSITION AND PROPERTIES OF J-10 GAS JACKET AND PRESSURE TUBE

\begin{tabular}{lcc}
\hline & Outer Loop, or Gas Jacket (a) & Inner Loop, or Pressure Tube (b) \\
\cline { 2 - 3 } Composition, w/o & 0.035 & 0.045 \\
Carbon & 1.59 & 1.60 \\
Manganese & 0.013 & 0.025 \\
Phosphorus & 0.018 & 0.015 \\
Sulfur & 0.56 & 0.42 \\
Silicon & 10.76 & 10.30 \\
Nickel & 18.66 & 19.85 \\
Chromium & 0.84 & .81 \\
Niobium & 0.10 &.- \\
Tantalum & $84,500-87,4.00$ & 91,300 to 93,000 \\
Tensile Strength, psi & & $53,500-60,700$ \\
O.2 Per Cent offset Yield Strength, psi & $36,300-43,300$ & $53.0-61.4$ \\
Elongation, per cent & $53.0-57.0$ & $68.0-72.1$ \\
\hline
\end{tabular}

(a) Composition fumished by Ladish of the billet which supplied the gas jacket. Mechanical properties were obtained on billets from opposite ends of the forging following $1000 \mathrm{~F}$ stress-relief heat treatment.

(b) Composition furnished by Thompson-Ramo-Wooldridge on finished component. Mechanical properties were obtained on billets from large and small ends of forging following rough machining and $1000 \mathrm{~F}$ stress-relief hot treatment.

The gas jacket was forged by Ladish. The forgings were heat treated for $1 \mathrm{hr}$ at $1950 \mathrm{~F}$ and water quenched. The forgings were then reheated to $1000 \mathrm{~F}$ for $1 \mathrm{hr}$ and water quenched. Tensile properties of the gas jacket, as determined by tests of material removed from opposite ends of the gas jacket, are given in Table 1. It can be observed from the table that the composition and fabrication conditions of both pressure tube and gas jacket were somewhat similar, although forging was accomplished at a higher temperature for the pressure tube. The tensile strength of the pressure tube was slightly higher, and the 0.2 per cent offset yield strength was appreciably higher than that of the gas jacket. Ductility, as indicated by the total elongation and reduction of area of both loop sections, was approximately equal to the preirradiation condition. 


\section{IN-PILE DESIGN PARAMETERS AND OPERATING HISTORY}

A list of the pertinent design and actual operating parameters associated with the $\mathrm{J}-10$ tube is given in Table 2. The list was compiled by Bettis Atomic Power Laboratory personnel from data supplied in part by the Phillips Petroleum Company ETR staff. It was observed that the actual operating conditions were somewhat less stringent than intended; however, the estimated maximum fast flux levels and total exposures were in excellent agreement with postirradiation data obtained at Battelle on samples with maximum neutron exposure. A calculated wall temperature profile versus the axial core position, as supplied by Bettis personnel, is given in Figure 1.

TABLE 2. OPERATING HISTORY OF THE J-10 PRESSURE LOOP DURING IRRADIATION FOR 38,794 MEGAWATT -DAYS IN THE ETR FOR A TOTAL ACCUMULATED FAST-NEUTRON (>1 MEV) EXPOSURE OF $7.15 \times 10^{21} \mathrm{NVT}^{(9)}$

\begin{tabular}{lcc}
\hline & Operating Conditions \\
& $\underline{\text { Design }}$ & Actual \\
& 2,500 & 2,200 \\
Pressure, psig & 14,100 & 12,400 \\
Pressure Stress, psi & 35 & 25 \\
Gamma Heat, w per g, peak & 600 & $450-500$ \\
Water Inlet Temperature, F & 268 & 191 \\
Wall $\triangle T$, F & 898 & $\sim 700$ \\
Maximum Wall Temperature, F & 67,200 & 48,000 \\
Thermal Stress, psi & 0,182 & 0.188 \\
Wall Thickness, in. & 30,000 (at $70 \mathrm{~F}$ ) & 62,500 (at $70 \mathrm{~F}$ ) \\
Yield Strength, psi & 75,000 (at 70 F) & 92,600 (at $70 \mathrm{~F}$ ) \\
Ultimate Strength, psi & &
\end{tabular}

\begin{tabular}{|c|c|c|c|c|c|}
\hline \multicolumn{6}{|c|}{ Exposure } \\
\hline Cycle & Megawatt-Days & Report & Cycle & Megawatt-Days & Report \\
\hline 22 & 595 & IDO-16595 & 29 & 2,129 & IDO -16619 \\
\hline 23 & 1,662 & IDO-16581 & 30 & 3,364 & IDO-16627 \\
\hline 24 & 975 & IDO-16585 & 31 & 1,358 & $1 D 0-16641$ \\
\hline 25 & 1,648 & IDO-16589 & 32 & 5,310 & IDO-16645 \\
\hline 26 & 3,063 & IDO-16598 & 33 & 5,086 & IDO-16649 \\
\hline 27 & 4,467 & IDO-16603 & 34 & 3,499 & IDO-16676 \\
\hline 28 & 4,134 & IDO-16618 & 35 & 1,505 & IDO-16680 \\
\hline
\end{tabular}

A schematic of the pressure tube and outer loop of the J-10 loop is shown in Figure 2. The section of the tube which passed through the reactor core was removed for testing. Both inner and outer tube sections arrived at Battelle in two pieces, a 19-in.long top and 17-in, -long bottom section. The inner loop was 2.200 in. in OD by 0.188 in. thick and the outer loop was $2.450 \mathrm{in}$. in OD by $0.092 \mathrm{in}$, thick. The north axis of the loop was identified prior to arrival at Battelle by a 1/4-in,-diameter hole drilled near the top of the upper sections and near the bottom of the lower sections. 


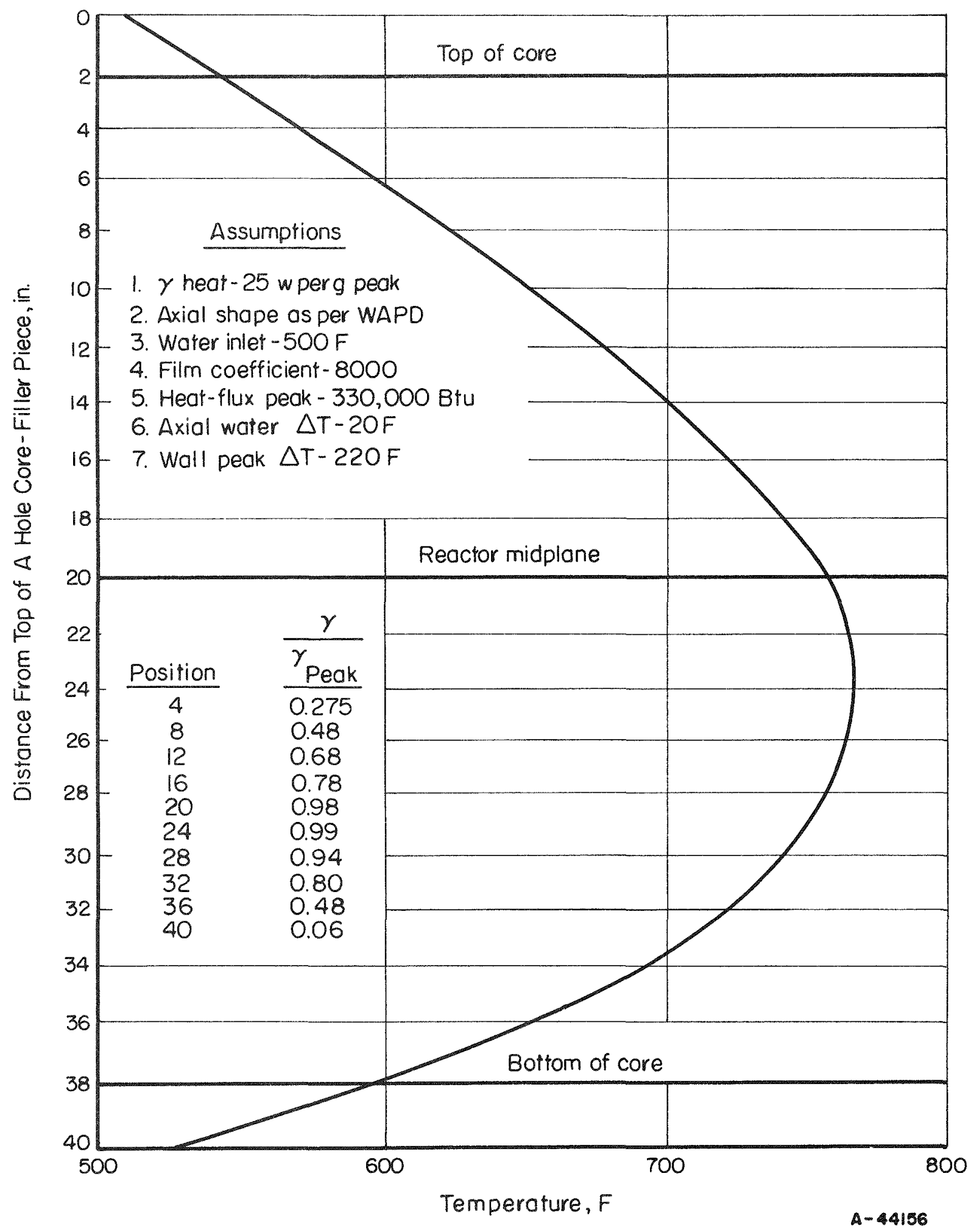

FIGURE 1. CALCULATED J-10 WALL TEMPERATURE 


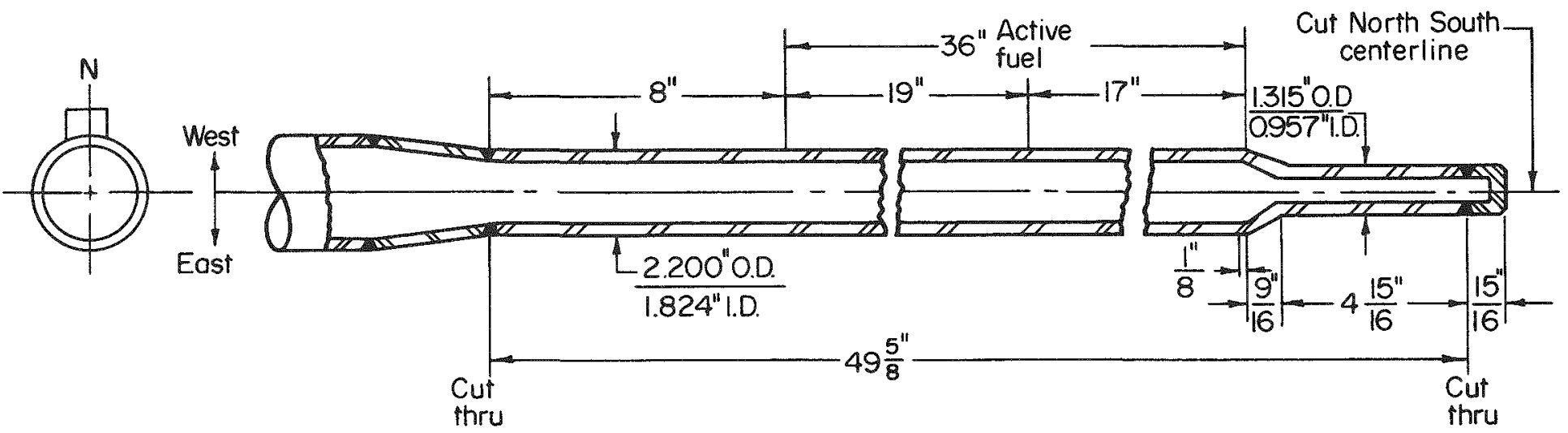

Pressure tube

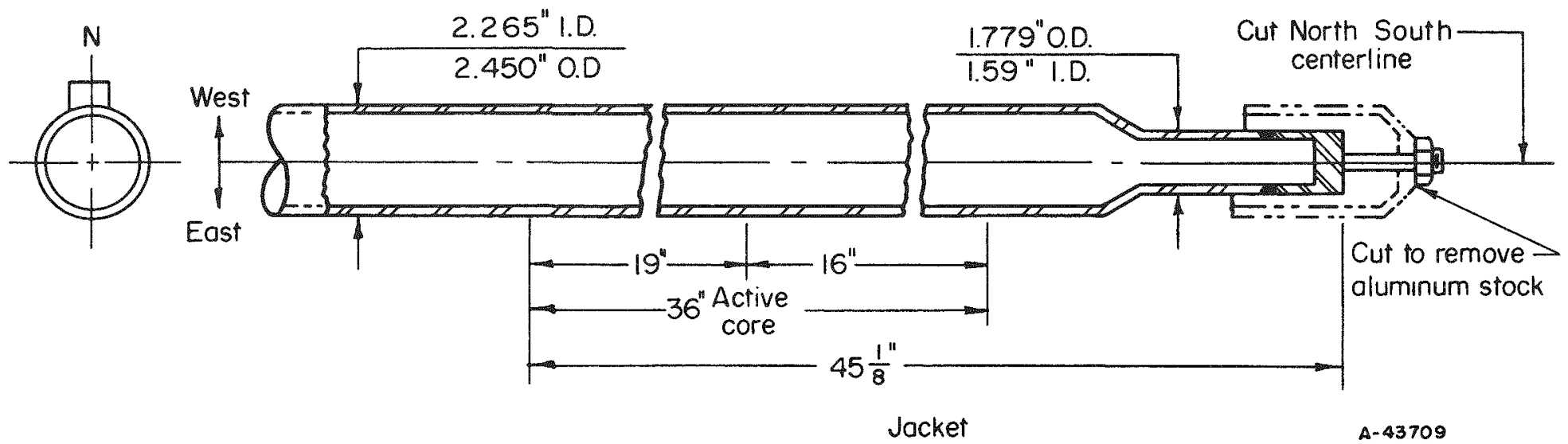

FIGURE 2. SCHEMATIC SECTION OF J-10 PRESSURE TUBE AND GAS JACKET 
HOT-CELL EXAMINATION

Surface Condition

Examination of the tubes was initiated shortly after they were received at the Battelle Hot-Cell Facility. The four tubes were viewed under a stereomacroscope and at this time it was noted that the surface of the inner loop, in particular, contained mottled areas indicative of selective oxidation. Temperature measurements obtained on the surface of the inner loop showed a $10 \mathrm{~F}$ higher temperature than ambient cell temperature, due to residual gamma heating. The temperature of the outer loop was not measured.

Sectioning of $\mathrm{J}-10$ Tubes

The pressure tube of the J-10 loop was slit into six approximately equal strips about $1.15 \mathrm{in}$. in width. This was sufficient to produce 36 approximately 5.0 -in. - long pieces suitable for machining into tensile specimens. Prior to cutting into specimen length, the strips were scanned to measure the intensity of the emitted gamma rays as a function of position along the length of the section. The procedure for slitting the loop sections was as follows:

(1) The tubes were mounted in a specially designed jig and slit longitudinally with a 1/32-in.-wide Norton A60-OE7 Alumdum abrasive wheel mounted on a shaft of a modified milling cutter.

(2) The initial cut on each tube was made through the identification hole located on the north axis. The tube was slit along the entire 17- or 19-in. length, then rotated clockwise 1.15 in. (circumferential measurement) and slitted again. Six strips approximately 1.12 in. wide were produced from both the top and bottom sections by this procedure from the pressure tube, while three strips plus a halfsection were produced from the outer loop sections.

(3) The strips were identified by indelible marker as they were removed from the tube sections in order to maintain original identity. The strips were numbered $S T-2$ through $S T-7$.

\section{Gamma Scan of Loop Strips}

The strips produced by the slitting techniques were subjected to scanning by a gamma-ray spectrometer in order to aid in selecting areas of low, intermediate, and high flux exposure for testing. The relative intensity of the gamma radiation emitted by the strips was determined from gamma-ray spectrographic traces made by adjusting the spectrometer for maximum activity response from $\mathrm{Mn}^{54}$ standards, and performing physical scans on strips at these energy settings. The $\mathrm{Mn}^{54}$ isotope, whose energy peak occurs at $0.835 \mathrm{Mev}$, was selected for scanning on the basis that it is produced in ironbearing materials by the nuclear reaction $\mathrm{Fe}^{54}(\mathrm{n}, \mathrm{p}) \mathrm{Mn}^{54}$. 
Traces were made on the top and bottom sections of each of the six strips using the techniques discussed above. Plots of the relative gamma intensity, as determined from the individual inner loop strips, were prepared; and upon the basis of plots, sections that received low, intermediate, and high levels of fast-neutron flux exposure were located and marked for subsequent sectioning. The location of the test specimens relative to calculated loop temperature and analyzed fast-neutron flux is shown graphically in Figure 3. The data shown in this figure include those from specimens tested in the as-irradiated condition (supported by AEC Division of Reactor Development funds) as well as those from the Bettis series of specimens which were annealed prior to testing. The latter data constitute the bulk of this report.

\section{Dosimetry}

The total fast-neutron exposure of the J-10 tube had been calculated on the basis of data from the phillips Petroleum Company. No attempt had been made to accumulate cycle-to-cycle data from analysis of either nickel- or iron-wire dosimeters. An estimate of the total fast flux was ascertained by utilizing the $\mathrm{Fe}^{54}(\mathrm{n}, \mathrm{p}) \mathrm{Mn}^{54}$ reaction and analyzing filings from individual specimens cut from the inner and outer tube. This reaction appeared worthy of consideration due to its longer half-life (300 days), an estimated cross section of 54 millibarns, and the fact that burnup due to thermal-neutron absorption was insignificant. The total fast fluxes calculated on the basis of these analyses are given in Table 3.

The technique followed for these determinations was as follows:

(1) A known weight of stainless steel was dissolved in hydrochloric acid and diluted to a known volume. An ion-exchange column was prepared by slurring Dowex $2-X-8,100$ to $200 \mathrm{mesh}$, in a glass tube $5 \mathrm{~cm}$ long with an inside diameter of about $1.3 \mathrm{~cm}$. In order to regulate the flow, a stopcock was placed below the column and an inlet funnel equipped with a stopcock and ground-glass joint was fitted above the column. The resin was initially activated by passing concentrated hydrochloric acid through the column at a rate of about $1 \mathrm{ml}$ per min.

(2) An aliquot of the dissolved specimen was placed on the column through the funnel. The $\mathrm{Mn}^{54}$ was eluted by passing $9 \mathrm{~N} \mathrm{HCl}$ through the column at about $1 \mathrm{ml}$ per min. An aliquot of the effluent was then radioassayed for $\mathrm{Mn}^{54}$.

The counting accuracy for the $\mathrm{Mn}^{54}$ has been shown to be within \pm 15 per cent. Although this limit of accuracy will present some scatter in values, the $F \mathrm{e}^{54}(\mathrm{n}, \mathrm{p}) \mathrm{Mn} \mathrm{n}^{4}$ reaction. can provide useful dosimeter data from the test samples themselves. Data from samples taken from specimens cut from the tube at approximately the same horizontal reactor core plane are shown in Figure 4. Some difference in values may have resulted from fracture location within the reference section. These graphs show, in addition to the scatter resulting from the counting accuracy, an effect related to location of the sample taken with respect to fuel location. Any radial variation would not have been detected as entire wall thickness was used as part of chemical-analysis sample. 
TABLE 3. TEST RESULTS OBTAINED ON IRRADIATED TENSILE

\begin{tabular}{|c|c|c|c|c|c|}
\hline \multirow[b]{2}{*}{ Specimen } & \multirow{2}{*}{$\begin{array}{l}\text { Approximate } \\
\text { Temperature } \\
\text { of Irradiation, } \\
\text { F }\end{array}$} & \multicolumn{3}{|c|}{ Fast-Neutron $(>1$ Mev) Flux Exposure $(a)$} & \multirow[b]{2}{*}{$\begin{array}{c}\text { Temperature } \\
\text { of Test, F }\end{array}$} \\
\hline & & \multicolumn{2}{|c|}{$\begin{array}{c}\text { Instantaneous, } \\
\text { nv } \\
\end{array}$} & $\begin{array}{l}\text { Integrated } \\
\text { nvt }\end{array}$ & \\
\hline & & & & & Gas Jacket, \\
\hline $\mathrm{LT}-4-\mathrm{L}-1$ & 120 & 0.91 & $1 \times 10^{14}$ & $1.8 \times 10^{21}$ & 75 \\
\hline$L T-4-I-2$ & 120 & 0.8 & $\times 10^{14}$ & $3.5 \times 10^{21}$ & 75 \\
\hline $\mathrm{LB}-3-\mathrm{H}$ & 120 & 3.4 & $\times 10^{14}$ & $6.5 \times 10^{21}$ & 75 \\
\hline Control & -- & & 0 & 0 & 75 \\
\hline$L T-3-L$ & 120 & 3.1 & $\times 10^{14}$ & $2.0 \times 10^{21}$ & 750 \\
\hline$L T-3-I$ & 120 & 2.4 & $\times 10^{14}$ & $4.5 \times 10^{21}$ & 750 \\
\hline$L T-3-H$ & 120 & 2.7 & $\times 10^{14}$ & $5.1 \times 10^{21}$ & 600 \\
\hline \multirow[t]{2}{*}{ Control } & -- & & 0 & 0 & 750 \\
\hline & & & & & Inner Loop, \\
\hline$S T-3-L$ & 510 & 1.0 & $\times 10^{14}$ & $1.9 \times 10^{21}$ & 75 \\
\hline$S T-2-I$ & 625 & 2.0 & $\times 10^{14}$ & $3.9 \times 10^{21}$ & 75 \\
\hline$S T-2-H$ & 735 & 3.7 & $\times 10^{14}$ & $7.1 \times 10^{21}$ & 75 \\
\hline$S T-2-\mathrm{L}$ & 540 & 1.1 & $\times 10^{14}$ & $2.1 \times 10^{21}$ & 750 \\
\hline$S B-2-I$ & 740 & 2.7 & $\times 10^{14}$ & $5.1 \times 10^{21}$ & 750 \\
\hline $\mathrm{SB}-2-\mathrm{H}$ & 760 & 3.6 & $\times 10^{14}$ & $6.9 \times 10^{21}$ & 750 \\
\hline Control(b) & $\ldots$ & & $=\infty$ & - & 70 \\
\hline \multirow[t]{2}{*}{ Handbook data (c) } & -- & & $-\infty$ & - & 750 \\
\hline & & & & & Inner Loop, \\
\hline$S T-7-\mathrm{L}$ & 540 & 0.87 & $7 \times 10^{14}$ & $1.7 \times 10^{21}$ & 75 \\
\hline$S T-7-I$ & 675 & 2.9 & $\times 10^{14}$ & $5.6 \times 10^{21}$ & 75 \\
\hline$S T-7 \mathrm{H}^{(\mathrm{d})}$ & 735 & 1.7 & $\times 10^{14}$ & $3.3 \times 10^{21}$ & 75 \\
\hline $\mathrm{SB}-7-\mathrm{L}$ & 700 & 1.2 & x $10^{14}$ & $2.3 \times 10^{21}$ & 750 \\
\hline$S B-7-I$ & 760 & 1.9 & $\times 10^{14}$ & $3.7 \times 10^{21}$ & 750 \\
\hline \multirow[t]{2}{*}{$S B-7-H$} & 760 & 3.4 & $\times 10^{14}$ & $6.5 \times 10^{21}$ & 750 \\
\hline & & & & & Inner Loops \\
\hline$S T-4-I$ & 680 & 0.0091 & $\times 10^{14}$ & $1.7 \times 10^{19}$ & 75 \\
\hline$S B-5-I$ & 760 & 0.52 & $\times 10^{14}$ & $1.0 \times 10^{21}$ & 75 \\
\hline $\mathrm{SB}-4-\mathrm{H}$ & 760 & & - & - & 75 \\
\hline $\mathrm{ST}-5-\mathrm{H}$ & 735 & 2.7 & $\times 10^{14}$ & $5.3 \times 10^{21}$ & 75 \\
\hline$S T-5-L$ & 510 & 2.6 & $\times 10^{14}$ & $5.0 \times 10^{21}$ & 750 \\
\hline$S B-3-I$ & 760 & & -- & $\ldots$ & 750 \\
\hline$S T-5-I$ & 670 & 1.2 & $\times 10^{14}$ & $2.3 \times 10^{21}$ & 750 \\
\hline$S T-3-H^{(e)}$ & 735 & & $\ldots$ & $-\infty$ & 750 \\
\hline \multirow[t]{2}{*}{$\mathrm{SB}-5-\mathrm{H}$} & 760 & 0.89 & $\times 10^{14}$ & $1.7 \times 10^{21}$ & 750 \\
\hline & & & & & Inner Loop, \\
\hline$S T-3-I(f)$ & 670 & 0.49 & x $10^{14}$ & $9.00 \times 10^{20}$ & 75 \\
\hline$S B-6-I$ & 760 & & $-\infty$ & $\ldots$ & 75 \\
\hline$S B-3-H$ & 760 & 3.4 & $\times 10^{14}$ & $6.50 \times 10^{21}$ & 75 \\
\hline $\mathrm{ST}-6-\mathrm{H}$ & 735 & 3.3 & $\times 10^{14}$ & $6.30 \times 10^{21}$ & 75 \\
\hline$S T-6-L^{(g)}$ & 510 & 0.047 & $\times 10^{14}$ & $9.00 \times 10^{19}$ & 750 \\
\hline$S B-4-I$ & 760 & & $\ldots$ & -- & 750 \\
\hline$S T-6-I$ & 670 & 2.4 & $\mathrm{x} 10^{14}$ & $4.60 \times 10^{21}$ & 750 \\
\hline$S T-4-H$ & 735 & & $-\infty$ & $-\infty$ & 750 \\
\hline $\mathrm{SB}-6-\mathrm{H}$ & 760 & 3.3 & $\times 10^{14}$ & $6.3 \times 10^{21}$ & 750 \\
\hline
\end{tabular}

(a) Exposures based on $\mathrm{Mn}^{54}$ ratio.

(b) From McInnes Company, reports on sample cut from as-machined J-10 pressure tube.

(c) Metals Handbook, Vol 1, Eighth Edition, p 503.

(d) Only $1.5 \mathrm{mg}$ of sample was analyzed. Small weighing errors could have caused large changes in analysis of exposure. Sample should have duplicated ST $-2-\mathrm{H}$. 
SPECIMENS MACHINED FROM SECTIONS OF THE J-10 LOOP

\begin{tabular}{|c|c|c|c|c|c|}
\hline $\begin{array}{c}0.2 \text { Per Cent Offset } \\
\text { Yield Strength, } \\
10^{3} \mathrm{psi}\end{array}$ & $\begin{array}{c}\text { Ultimate Tensile } \\
\text { Strength, } \\
10^{3} \mathrm{psi}\end{array}$ & $\begin{array}{l}\text { Fracture } \\
\text { Strength, } \\
10^{3} \mathrm{psi}\end{array}$ & $\begin{array}{c}\text { Uniform } \\
\text { Elongation, } \\
\text { per cent }\end{array}$ & $\begin{array}{c}\text { Total } \\
\text { Elongation, } \\
\text { per cent }\end{array}$ & $\begin{array}{l}\text { Reduction } \\
\text { of Area, } \\
\text { per cent }\end{array}$ \\
\hline \multicolumn{6}{|l|}{ Initial Test Run } \\
\hline 100.0 & 103.5 & 191.0 & $>18.0$ & 31.0 & 54.6 \\
\hline 95.2 & 101.3 & 192.5 & $>14.8$ & 26.0 & 57.0 \\
\hline 102.5 & 108.0 & 226.0 & $>18.6$ & 25.0 & 60.5 \\
\hline 46.8 & 99.7 & - & $>8.5$ & 50.4 & 61.8 \\
\hline 62.5 & 66.7 & 118.0 & -- & 13.5 & 54.0 \\
\hline 65.4 & 69.3 & 123.0 & 7.7 & 11.5 & 54.6 \\
\hline 71.8 & 73.3 & 115.0 & 9.0 & 12.5 & 48.3 \\
\hline 36.5 & 67.6 & - & -- & 26.2 & 62.9 \\
\hline \multicolumn{6}{|l|}{ Initial Test Run } \\
\hline 132.0 & 135.0 & 215.0 & 1.2 & 4.3 & 53.5 \\
\hline 143.0 & 145.0 & 231.0 & 1.2 & 6.5 & 54.5 \\
\hline 143.0 & 149.0 & 250.0 & 2.0 & 10.3 & 58.2 \\
\hline 103.0 & 103.0 & 124.0 & 0.6 & 4.5 & 42.7 \\
\hline 115.0 & 115.0 & 138.0 & 0.7 & 1.5 & 40.8 \\
\hline 120.0 & 120.0 & 175.0 & 0.8 & 3.5 & 52.5 \\
\hline $52.5-60.7$ & $91.3-93.0$ & - & -- & $53-61$ & $58-72$ \\
\hline $40-50$ & $70-80$ & - & $\cdots$ & $45-50$ & $-\infty$ \\
\hline \multicolumn{6}{|l|}{ Duplicate Test Run } \\
\hline 130.0 & 134.0 & 247.0 & 2.0 & 6.5 & 59.1 \\
\hline 139.5 & 144.8 & 264.0 & 1.8 & 10.6 & 59.8 \\
\hline 143.0 & 147.0 & 278.0 & 1.0 & 9.4 & 61.5 \\
\hline 115.3 & 115.3 & 239.0 & 0.6 & 4.2 & 64.0 \\
\hline 123.0 & 123.5 & 162.0 & 0.7 & 4.2 & 45.5 \\
\hline 123.6 & 125.8 & 150.0 & 0.8 & 4.1 & 40.5 \\
\hline \multicolumn{6}{|c|}{ Annealed for $1 \mathrm{Hr}$ at $1000 \mathrm{~F}$} \\
\hline 77.5 & 99.0 & 190.0 & $>16.0$ & 35.5 & 58.7 \\
\hline 72.3 & 98,0 & 183.0 & $>20.0$ & 44.3 & 56.2 \\
\hline 69.4 & 94.5 & 193.5 & $>15.0$ & 38.0 & 59.1 \\
\hline 75.0 & 96.0 & 208.0 & $>14.0$ & 41.0 & 63.3 \\
\hline 47.5 & 64.0 & 101.0 & $>18.0$ & 24.0 & 50.2 \\
\hline 55.0 & 75.4 & 108.5 & 14.2 & 21.2 & 50.8 \\
\hline 58.0 & 71.4 & 118.5 & 11.9 & 19.5 & 55.2 \\
\hline 87.5 & 88.5 & 122.5 & 1.1 & 7.5 & 47.3 \\
\hline 54.4 & 69.2 & 117.5 & 11.1 & 16.6 & 55.8 \\
\hline \multicolumn{6}{|c|}{ Annealed for $1 \mathrm{Hr}$ at $1800 \mathrm{~F}$} \\
\hline 51.4 & 85.5 & 145.0 & $>26.0$ & 42.9 & 49.9 \\
\hline 38.4 & 87.8 & 132.0 & $>24.0$ & 49.0 & 37.1 \\
\hline $\begin{array}{l}55.8 \\
36.5\end{array}$ & $\begin{array}{l}86.5 \\
77.5\end{array}$ & $\begin{array}{l}130.0 \\
121.0\end{array}$ & $\begin{array}{l}>25.0 \\
>25.0\end{array}$ & $\begin{array}{l}51.0 \\
41.2\end{array}$ & $\begin{array}{l}42.9 \\
36.9\end{array}$ \\
\hline 20.8 & 61.0 & 95.0 & $>27.0$ & 35.9 & 46.3 \\
\hline 44.7 & 65.4 & 120.0 & 18.0 & 23.4 & 58.0 \\
\hline 33.0 & 62.5 & 87.5 & $>21.5$ & 26.2 & 42.9 \\
\hline 43.6 & 61.5 & 96.2 & 14.5 & 20.1 & 53.6 \\
\hline 27.2 & 62.5 & 172.0 & $>28.0$ & 41.2 & 67.3 \\
\hline
\end{tabular}

(e) Erratic thermocouple operation resulted in annealing temperature below $1000 \mathrm{~F}$.

(f) Annealing temperature went to $1930 \mathrm{~F}$ for $2 \mathrm{~min}$, then decreased to $1800 \mathrm{~F}$ in abour $6 \mathrm{~min}$.

(g) Annealing temperature went to $1950 \mathrm{~F}$ for $3 \mathrm{~min}$, then decreased to $1800 \mathrm{~F}$ in about $7 \mathrm{~min}$. 


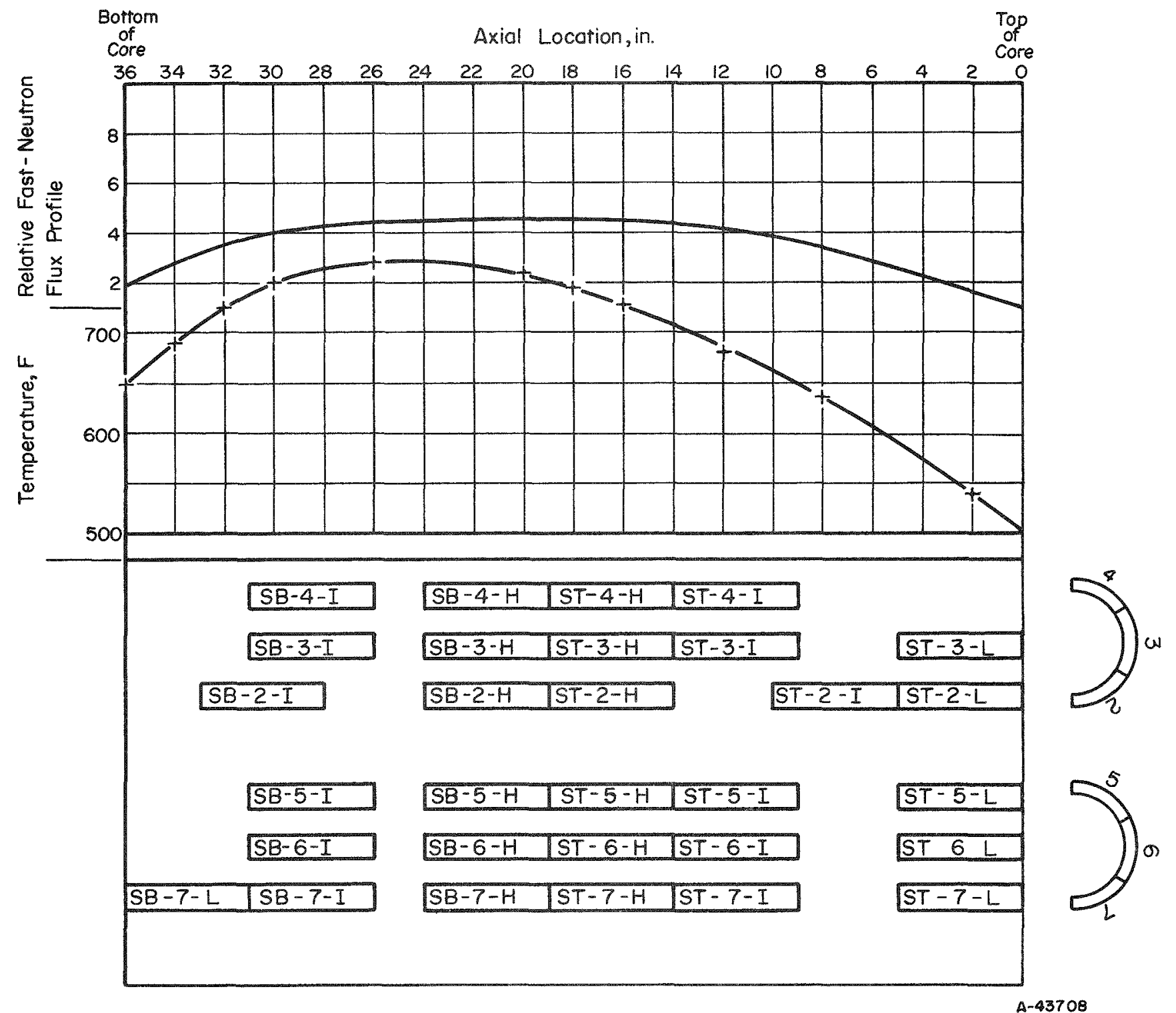

FIGURE 3. TEMPERATURE AND RELATIVE FLUX PROFILE OF J 10 PRESSURE TUBE AND SPECIMEN LOCATIONS 

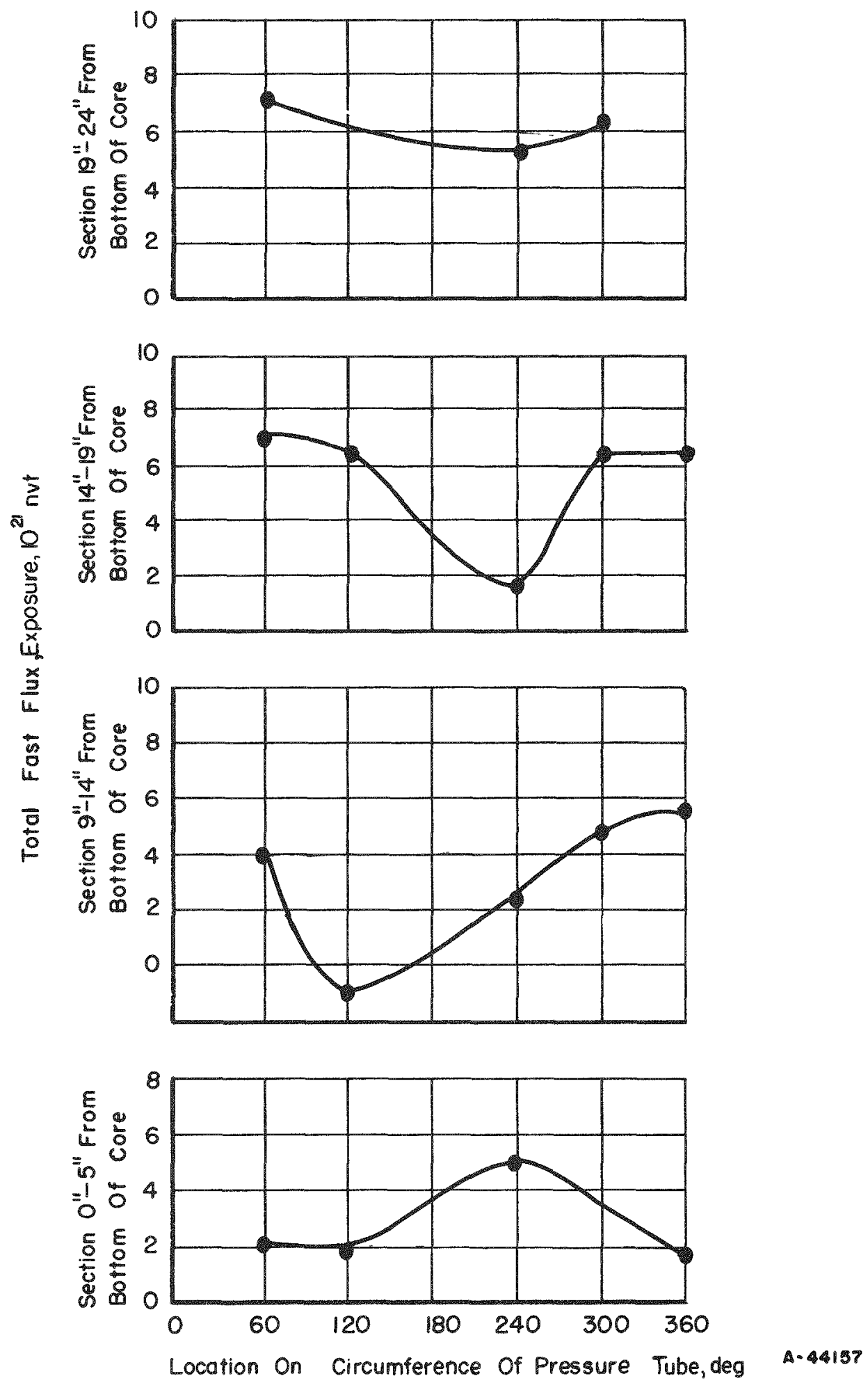

FIGURE 4. ESTIMATED TOTAL FAST FLUX EXPOSURE WITH RESPECT TO LOCATION ON PRESSURE TUBE AS DETERMINED BY Mn 54 ANALYSIS 
Heat Treatment of Specimen Blanks

A total of eighteen ir radiated specimen blanks removed from various exposure levels of the J-10 inner loop were annealed at BMI according to information received from personnel at Bettis. Those blanks receiving the annealing treatments included nine which were heated for $1 \mathrm{hr}$ at $1000 \mathrm{~F}$ and nine which were heated for $1 \mathrm{hr}$ at $1800 \mathrm{~F}$. A 5-kw Lepel electronic power supply was used in conjunction with a specially designed induction core contained in a Plexiglas cover to provide the required thermal conditions. Specimen temperatures were monitored by means of a thermocouple positioned in the center of each specimen blank. An argon flow of $35 \mathrm{ft}^{3}$ per min (in the case of the $1000 \mathrm{~F}$ anneal) or $45 \mathrm{ft}^{3}$ per min (1800 F anneal) was used as a protective cover during the period of temperature annealing. A series of out-of-cell heating tests on unirradiated Type 347 stainless steel segments of similar geometry established the proper power adjustment necessary to maintain the required heating and cooling sequences. The heating and cooling sequences requested by Bettis Atomic Power Laboratory personnel were as follows:

(1) $1000 \mathrm{~F}$ anneal: The specimen was heated at $200 \mathrm{~F}$ per min to $1000 \mathrm{~F}$, held at this temperature for $1 \mathrm{hr}$, and cooled at $25 \mathrm{~F}$ per min to $600 \mathrm{~F}$. The total elapsed time was about $1 \mathrm{hr} 25 \mathrm{~min}$.

(2) $1800 \mathrm{~F}$ anneal: The specimen was heated at a rate of $200 \mathrm{~F}$ per min to $1000 \mathrm{~F}$, at $125 \mathrm{~F}$ per min to $1500 \mathrm{~F}$, at $30 \mathrm{~F}$ per min to $1800 \mathrm{~F}$, held at $1800 \mathrm{~F}$ for $1 \mathrm{hr}$, then cooled to $1000 \mathrm{~F}$ at a rate of about $57 \mathrm{~F}$ per min and from 1000 to $600 \mathrm{~F}$ at $25 \mathrm{~F}$ per min. The total elapsed time was about $1 \mathrm{hr} 50 \mathrm{~min}$.

In most of the annealing tests it was possible to maintain the thermal conditions requested by BAPL. The proper heating conditions were rather easily maintained, although cooling rates at the higher temperature anneal gave some difficulty to achieve. In two instances, temperature overrides to about $1950 \mathrm{~F}$ were observed; in a third case, $\mathrm{R}-\mathrm{F}$ feedback into the temperature recordex caused it to record a higher temperature than actually prevailed in the specimen. Representative temperature curves for the 1000 and $1800 \mathrm{~F}$ anneals are shown in Figure 5.

Machining of the Tensile-Test Specimens

The tensile-specimen geometry selected for evaluating core sections of the J-10 loop was dictated to some extent by the curvature of the loop and the amount of material available. The size of the specimens ultimately prepared for evaluation included an over-all length of $5 \mathrm{in}$; a gage section $2.0 \mathrm{in}$. long by $0.250 \mathrm{in}$. wide, and a shoulder width of $1.12 \mathrm{in}$. This thickness of the inner loop specimens was about 0.187 in. This is not standard for sheet-type tensile specimens, but was considered of sufficient size to give good results. A drawing of the specimen design ultimately selected for testing is shown in Figure 6.

Considerable difficulty was encountered in machining of the as-irradiated stainless steel billets into tensile specimens. Initial attempts were made to machine the tensile specimens by means of a 1 -in. -diameter end-mill cutter attached to a conventional milling machine. When this method proved ineffective because of the combined effects of 


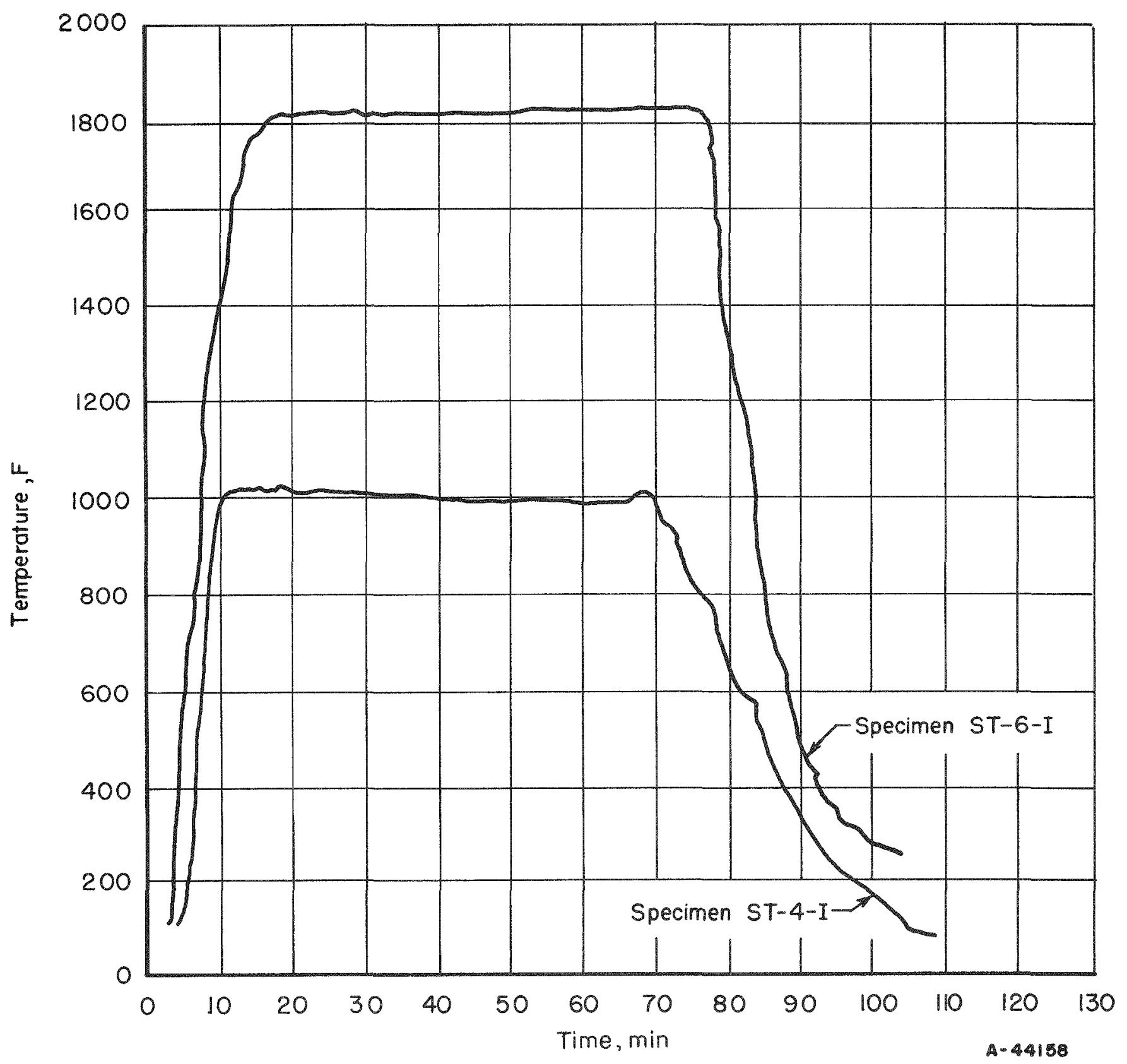

FIGURE 5. REPRESENTATIVE TIME-TEMPERATURE CURVES FOR SPECIMENS GIVEN 1-HR ANNEALS 


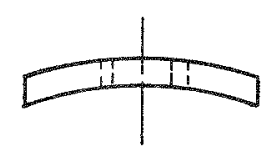

Specimen thickness:

Inner loop 0.188"

Outer jocket 0.092 "

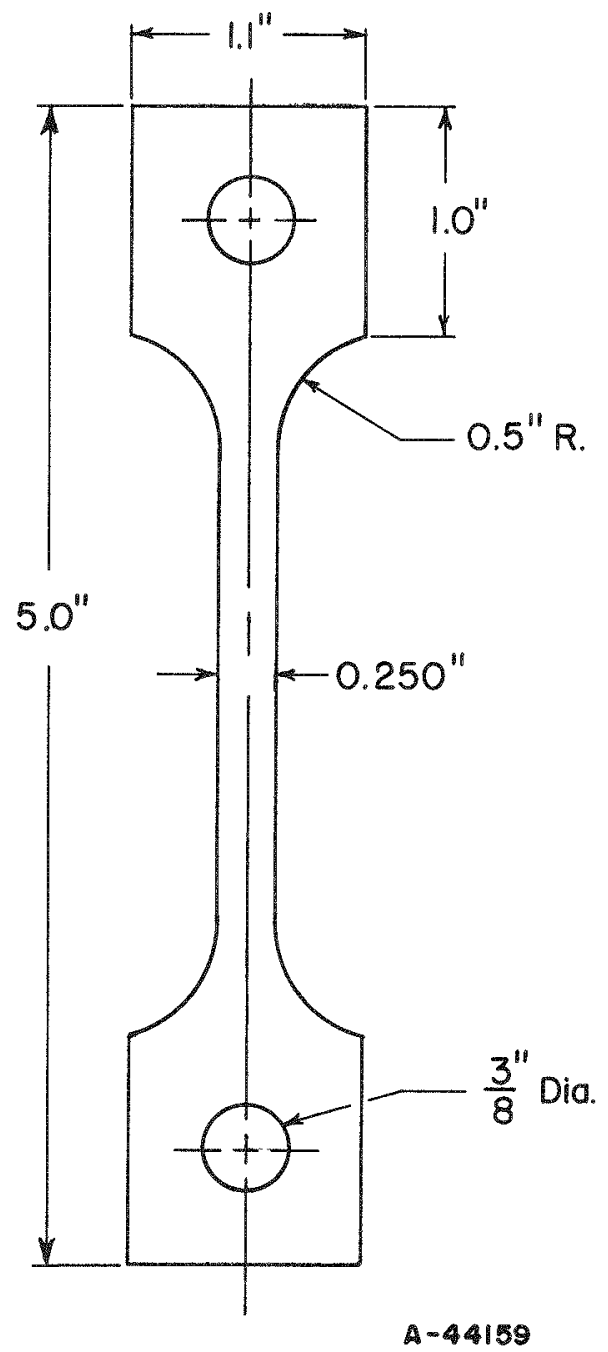

FIGURE 6. CURVED TENSILE SPECIMENS MACHINED FROM J-10 LOOP

The outer jacket was $2.265 \mathrm{in}$. in $O D$ and $2.450 \mathrm{in.}$ in ID; the inner loop was $2.200 \mathrm{in}$. in OD and $1.824 \mathrm{in}$. in ID. 
radiation hardening and work hardening, a newly designed cutting tool was constructed to perform the machining task. This cutting tool consisted of an air-driven, high-speed motor connected to a carbide-tipped rotary file. A series of cams was used to guide the cutter and establish the necessary specimen geometry. By means of this cutter, it was possible to remove 2 to 4 mils of metal from the workpiece per pass. Tests on unirradiated samples of Type 347 stainless steel showed that this material was not work hardened during cutting, probably due to the small size of the cutter and its very high rate of rotation. Temperature measurements obtained by thermocouples placed adjacent to the cutter showed a temperature rise of only $30 \mathrm{~F}$ during cutting.

The difficulty noted above was not nearly so pronounced in machining of the annealed specimens. Generally, the specimens were machined with no more difficulty than is normally encountered in machining unirradiated stainless steel. The relative ease with which the machining of the annealed billets was accomplished was indicative of the large decrease in hardness resulting from the heat treatment.

\section{Tensile-Testing Experimental Procedure}

The irradiated J-10 specimens were tested either at room temperature (about $75 \mathrm{~F}$ ) or $750 \mathrm{~F}$. Those specimens tested at the elevated temperature were heated in a 3 -in. diameter resistance furnace that enclosed the grip ends of the tester to minimize heat losses from the ends of the specimen. Test specimens wexe placed in the furnace, brought to $750 \mathrm{~F}$, and held at that temperature 30 min prior to the application of a load to the sample. Specimen temperatures were monitored by thermocouples strapped to the center gage section of each specimen.

The specimens were tested with a Riehle Model PH-30 tensile tester, using a strain rate of 0.005 in. per in. per min from point of yield to specimen fracture. Specimen elongation was measured and recorded with a Riehle Model DC-10 compressometer whose output signal activated one leg of an $\mathrm{x}-\mathrm{y}$ recorder. Load-versus-elongation curves were autographically obtained. The data obtained from these tensile tests were converted to normal stress-versus-strain data and are reported in Table 3. Also included in the table for comparison are data from a series of tests of the same material and exposures but in the as-irradiated condition. These data on as-irradiated material are discussed in BMI-1609.

The uniform elongation was determined by ascertaining and recording the elongation at maximum load from the load-versus-strain curves. The maximum load was well defined in most instances, but for tests in which it was not because of the range limitation of the compressometer, the uniform elongation is reported greater than the total elongation recorded. Total-elongation measurements were based on measurements made by fitting the fractured specimen together and measuring its total length after fracture. It was assumed that the plastic deformation occurred in the reduced gage section.

Photographs of the fracture zone from the front and the side of each specimen were made at $4 X$ magnification. These are shown in Figures $A-1$ through $A-24$ in the Appendix. The reduction-of-area calculations were made by measuring the width and thickness of the samples at the fractures to determine the specimen area at fracture. These measurements were made from the photographs by comparing with a scale graduated into $0.01-i n$. divisions which had been photographed at $4 \mathrm{X}$ magnification along with each specimen. The fracture strength was calculated by using the load at fracture and dividing by the calculated cross-sectional area at fracture. 
Test Results

A comparison of the pre- and postirradiation mechanical properties showed that the yield and ultimate strengths of the Type 347 stainless steel were greatly increased following irradiation, whereas the ductility, as reflected by decreases in reduction of area, uniform elongation, and total elongation, was decreased. The most startling results were those that revealed that the pressure-tube, irradiated in the stressed state and at about $750 \mathrm{~F}$, gave values for ultimate strength and 0.2 per cent yield strength that were approximately 35 to 40 per cent greater than for the gas jacket, which was irradiated at $120 \mathrm{~F}$ in the unstressed condition. The total elongation showed a decrease of about 80 per cent for the pressure tube as compared to the gas jacket. Increased test temperatures seemed to increase the spread in property values between the pressure tube and the gas jacket.

The effect of postirradiation annealing at 1000 and $1800 \mathrm{~F}$ upon the mechanical properties of specimens machined from the J-10 loop was to reduce the ultimate and yield strength and increase the ductility. Using the as-irradiated properties of Type 347 stainless steel as a base, the 0.2 per cent yield strength was decreased about 41 to 51 per cent and 62 to 75 per cent after annealing specimens for $1 \mathrm{hr}$ at $1000 \mathrm{~F}$ or $1 \mathrm{hr}$ at $1800 \mathrm{~F}$, respectively. The ultimate-strength values were also decreased by about 31 to 43 per cent and 40 to 51 per cent after $1 \mathrm{mhr}$ anneals of 1000 and $1800 \mathrm{~F}$, respectively. There did not seem to be a correlation between the amount of recovery of tensile properties obtained by annealing with the levels of irradiation exposure the specimens had received. The largest change noted upon annealed specimens was an increase in ductility. Changes of several hundred per cent over the as-irradiated values were produced by both annealing treatments.

Both annealing temperatures were effective in producing partial recovery of the preirradiation mechanical properties of the Type 347 stainless steel, but of the two, the 1-hr anneal at $1000 \mathrm{~F}$ appeared to produce the best combination of mechanical properties for further service. A substantially higher yield strength is retained after the lower temperature anneal than after annealing at $1800 \mathrm{~F}$.

The appearance of the fractures produced in test specimens of the $\mathrm{J}-10$ pressure loop is shown in Figure 7. Included are photomacrographs of as-irradiated high- and low-exposure specimens and high-and low-exposure specimens tested after 1-hr anneals at 1000 and $1800 \mathrm{~F}$. The photomacrographs show that necking in the region of fracture is reduced in specimens that received the $1-\mathrm{hr}$ anneals, particularly in the specimens receiving the $1800 \mathrm{~F}$ anneal. This is interpreted as an indication of increased uniform elongation, rather than localized deformation in the region of fracture only.

\section{Hardness}

In addition to the use of tensile properties as a measure of irradiation effect, Rockwell hardness measurements were made on the shoulder of each tensile sample. Comparisons were made between the hardness as irradiated and the hardness after annealing. The average hardness of the as-irradiated material was about 32.0 on the Rockwell $\mathrm{C}$ scale. After $1 \mathrm{hr}$ at $1000 \mathrm{~F}$ the hardness was decreased to about 8 Rockwell C. Irradiated materials annealed $1 \mathrm{hr}$ at $1800 \mathrm{~F}$ showed a still further reduction 


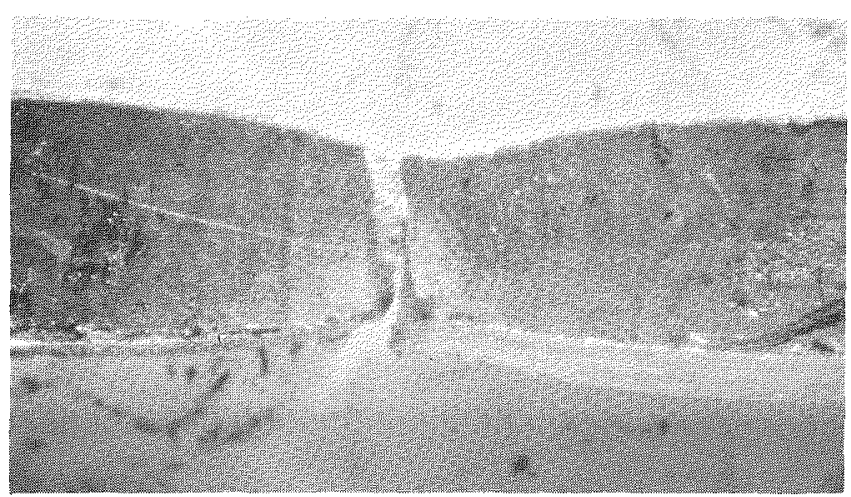

$4 \mathrm{X}$

Low -Flux-Exposure Specimen

$\mathrm{HC} 10075$

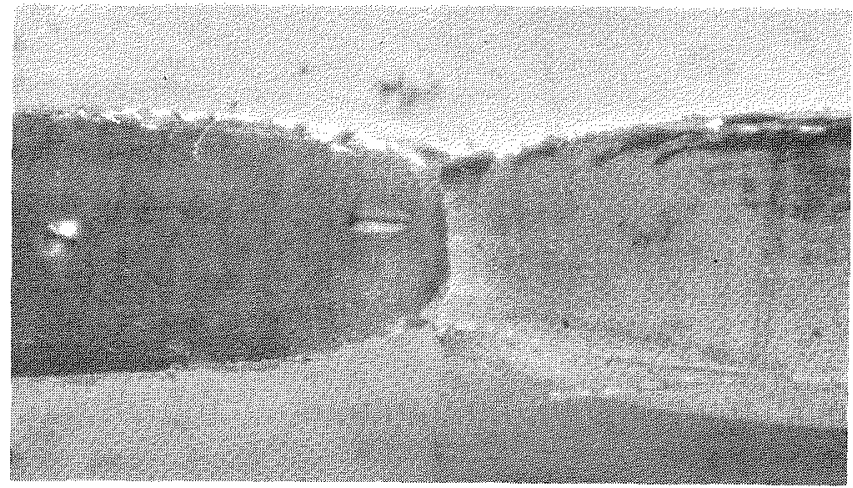

$4 \mathrm{X}$

HC10069

a. Specimens Tested in the As-Irradiated Condition

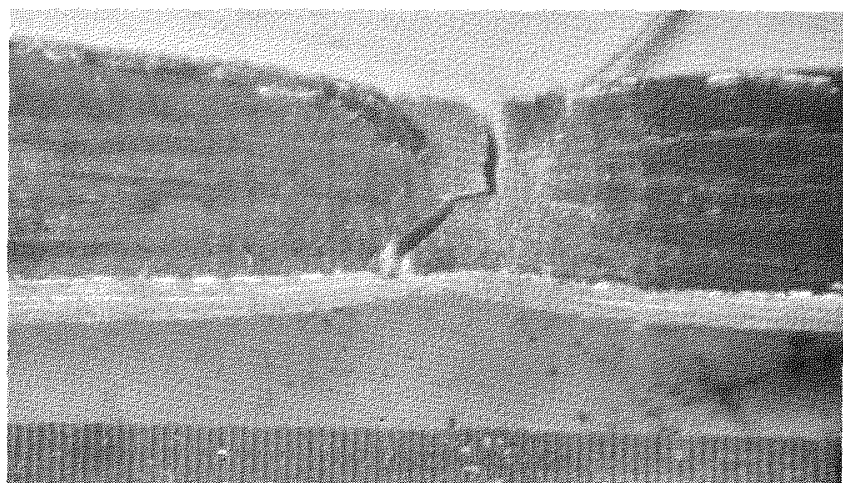

$4 X$

Low -Flux-Exposure Specimen

$\mathrm{HC} 10103$

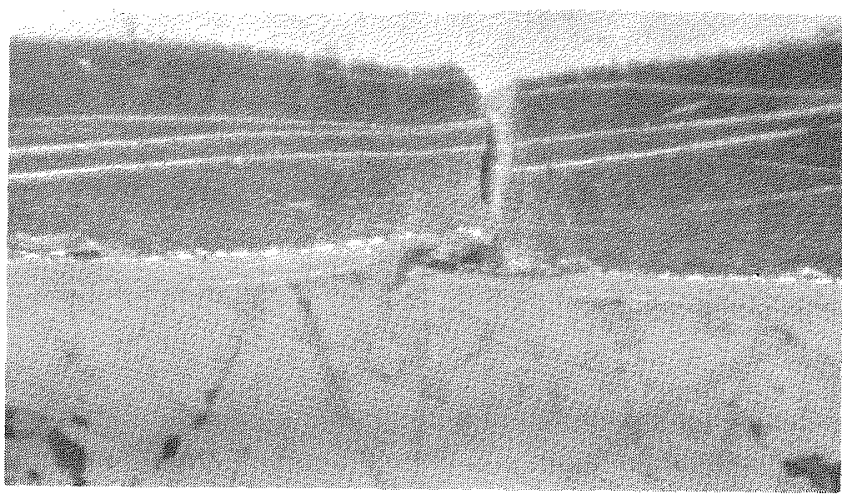

$4 \mathrm{X}$

HC10109

High-Flux-Exposure Specimen

b. Specimens Tested After 1-Hr Anneal at $1000 \mathrm{~F}$

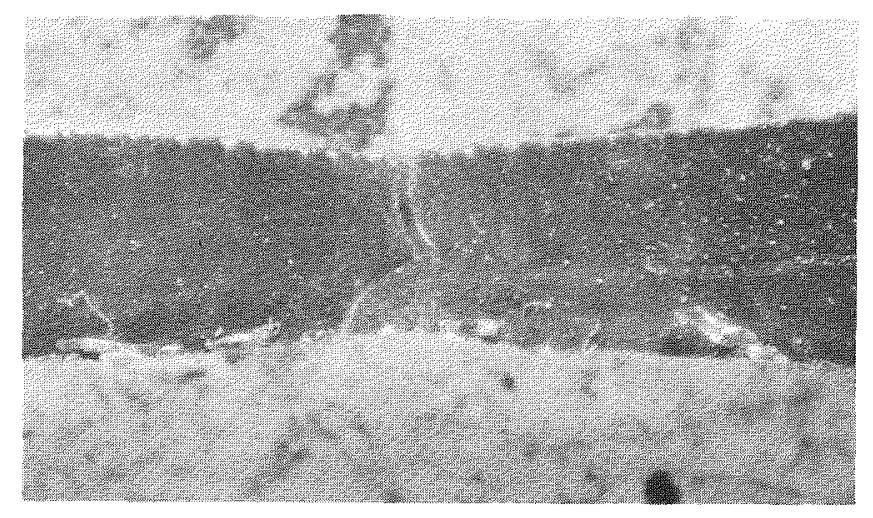

$4 X$
HC10114 4X

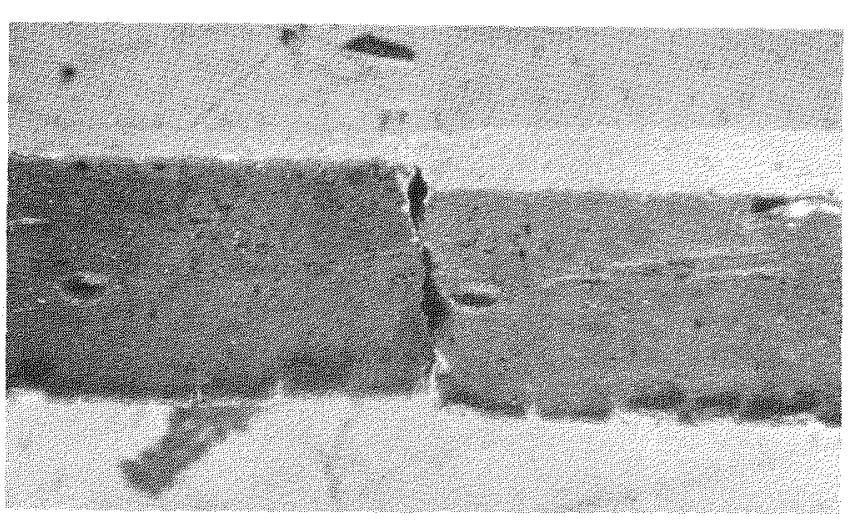

High-Flux-Exposure Specimen

High-Flux -Exposure Specimen

Low-Flux-Exposure Specimen

c. Specimens Tested After 1-Hr Anneal at $1800 \mathrm{~F}$

FIGURE 7. APPEARANCE OF FRACTURED TENSILE SPECIMENS OF DIFFERENT TEST CONDITIONS 
in hardness. The hardness was found to be in the range 38 to 55 on the Rockwell A scale. Conversion of these Rockwell A readings to the Rockwell C scale shows that the higher readings correspond to about 2 or 3 Rockwell C.

These changes in hardness are summarized in Table 4. It can also be noted that there was only a slight variation in hardness of the as-irradiated specimens representing different irradiation exposures. Although little difference was observed in the hardness of the as-irradiated specimens, the hardness values obtained after annealing indicate greater recovery effects in the specimens from regions of the pressure tube receiving a lower irradiation exposure. This was apparent for both the $1000 \mathrm{~F}$ and $1800 \mathrm{~F}$ annealing heat treatments.

TABLE 4. HARDNESS OF J-10 PRESSURE-TUBE SPECIMENS BEFORE AND AFTER HEAT TREATMENT AT 1000 AND $1800 \mathrm{~F}$

\begin{tabular}{|c|c|c|c|}
\hline \multirow[b]{2}{*}{ Specimen (a) } & \multicolumn{3}{|c|}{ Hardness (b) } \\
\hline & $\begin{array}{c}\text { Rockwell C } \\
\text { Before } \\
\text { Heat Treatment } \\
\end{array}$ & $\begin{array}{c}\text { Rockwell C } \\
\text { After } 1 \mathrm{Hr} \text { at } \\
1000 \mathrm{~F}\end{array}$ & $\begin{array}{c}\text { Rockwell A } \\
\text { After } 1 \mathrm{Hr} \text { at } \\
1800 \mathrm{~F}\end{array}$ \\
\hline$S T-4-I$ & 32.4 & 5.8 & -- \\
\hline$S B-5-I$ & 30.6 & 10.6 & -- \\
\hline$S B-4-H$ & 32.8 & 15.6 & -- \\
\hline $\mathrm{ST}-5-\mathrm{H}$ & 34.8 & 11.2 & $-\sim$ \\
\hline$S T-5-L$ & 32.6 & 2.4 & - \\
\hline$S B-3-I$ & 33.4 & 3.6 & $-\infty$ \\
\hline$S T-5-I$ & 32.2 & 10.6 & $-\infty$ \\
\hline $\mathrm{ST}-3-\mathrm{H}$ & 34.6 & 14.8 & - \\
\hline$S B-5-H$ & 31.8 & 14.2 & - \\
\hline$S T-3-I$ & 33.8 & - & 53.2 \\
\hline$S B-6-I$ & 33.6 & -- & 50.8 \\
\hline$S B-3-H$ & 31.0 & $-\cdots$ & 55.0 \\
\hline $\mathrm{ST}-6-\mathrm{H}$ & 34.4 & $\ldots$ & 46.0 \\
\hline$S T-6-L$ & 32.8 & -- & 42.4 \\
\hline$S B-4-I$ & 32.8 & -- & 37.8 \\
\hline$S T-6-I$ & 31.4 & - & 51,2 \\
\hline$S T-4-H$ & 33.8 & - & 54.2 \\
\hline$S B-6-H$ & 31.2 & -- & 48.4 \\
\hline
\end{tabular}

(a) Letter suffix indicates amount of irradiation exposure: $\mathrm{H}=$ high, $\mathrm{I}=$ intermediate, and $\mathrm{L}=1 \mathrm{l}$.

(b) Average of five hardness impressions.

Metallographic Examination

Metallographic examinations were performed upon shoulder sections of several tensile specimens. The examinations included as-irradiated specimens from sections receiving low, intermediate, and high irradiation exposures as well as specimens representing exposures that were subjected to postirradiation anneals of $1 \mathrm{hr}$ at 1000 or $1800 \mathrm{~F}$. 
Examinations were performed on the as-polished specimens, and after etching with a glyceregia swab etch or 10 per cent oxalic acid electroetch. It was noted that the structure of all of the specimens examined was similar, and it was not possible, except in two instances, to delineate, on the basis of microstructure alone, the as-irradiated specimens from specimens annealed after irradiation and/or control samples. The two exceptions were the specimens which had been unintentionally heated above $1800 \mathrm{~F}$. One had a very large grained structure, apparently caused by the overheating. The second specimen had a lesser amount of grain growth, but exhibited a second phase in some of the grain boundaries. The second phase at the grain boundaries may be similar to the heavy uneven carbide reported by Bailey and Silliman in postirradiation-annealed Type 347 stainless steel.(2)

Typical microstructures of $\mathrm{J}-10$ pressure-tube material before and after irradiation and after postirradiation annealing at 1000 and $1800 \mathrm{~F}$ are shown in Figure 8 . Microstructures of the two specimens inadvertently overheated are shown in Figure 9.

\section{CONCLUSIONS}

The effects of $1-\mathrm{hr}$ anneals at 1000 and $1800 \mathrm{~F}$ upon property changes of specimens machined from an AISI Type 347 stainless steel pressure tube from an in-pile loop have been determined. This pressure tube was removed from the ETR J-10 position in March, 1961, after having been exposed to approximately 38,800 megawatt-days of fullpower operation at a maximum in-pile temperature of about $780 \mathrm{~F}$. The following information relevant to the effects of these anneals on the irradiated Type 347 stainless steel was obtained:

(1) Using as-irradiated properties of the J-10 pressure tube as a base, the 0.2 per cent offset yield strength decreased about 41 to 51 and 62 to 75 per cent, after $1-\mathrm{hr}$ anneals at 1000 and $1800 \mathrm{~F}$, respectively.

(2) The ultimate strength decreased from as-irradiated values by about 31 to 43 and 40 to 51 per cent after $\mathrm{l}-\mathrm{hr}$ anneals at 1000 and $1800 \mathrm{~F}$, respectively.

(3) The ductility, as reflected by elongation, was greatly increased by annealing. Uniform elongations were increased from approximately 1 per cent in the as-irradiated material to 15 and 25 per cent by the 1000 and $1800 \mathrm{~F}$ anneals, respectively. Uniform elongation was noted in annealed specimens within the entire gage section, rather than localized elongation which was observed only in the area of fracture of as-irradiated specimens.

(4) The 1-hr anneal at $1000 \mathrm{~F}$ appeared to produce a better combination of mechanical properties than the annealing at the higher temperature. The higher temperature anneal produced, in general, lower ultimate and yield strengths in the irradiated specimens than were present in the unirradiated controls. 


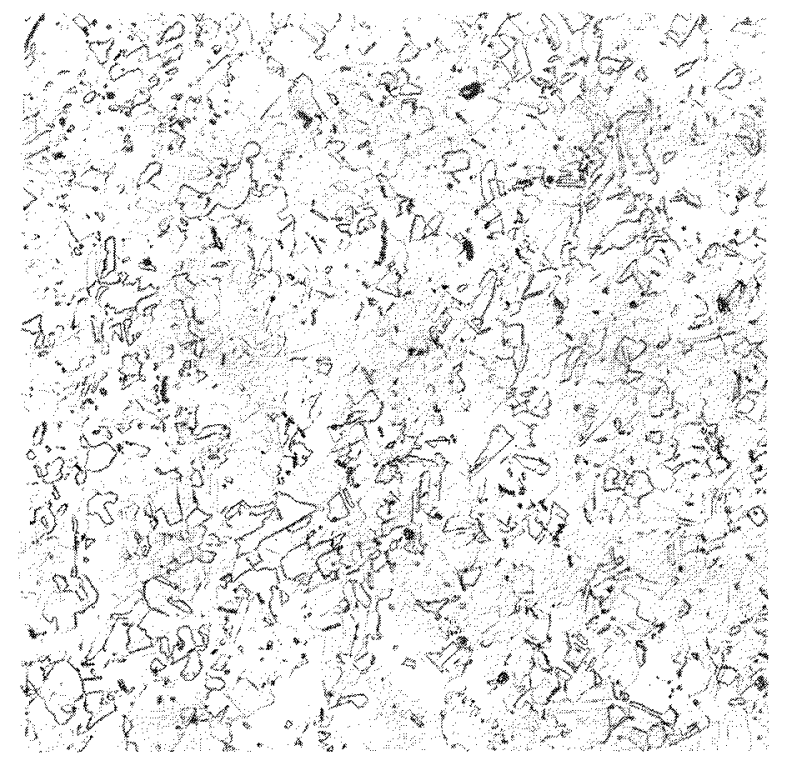

$100 \mathrm{X}$

Etched

a. Unirradiated WAPD Photo

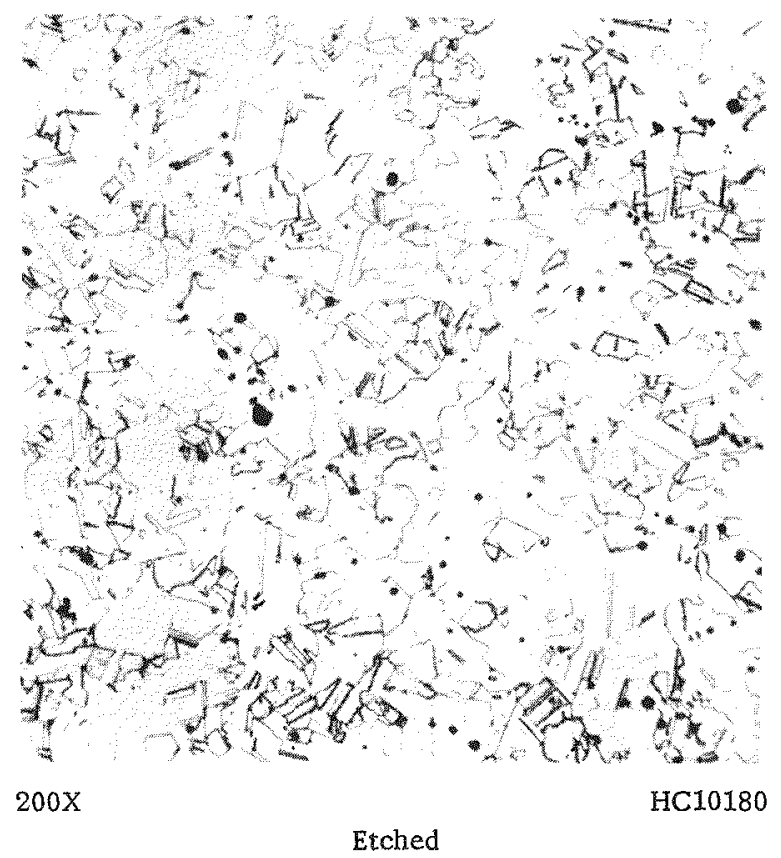

c. Irradiated to $5.3 \times 10^{21}$ NVT and Annealed $1 \mathrm{Hr}$ at $1000 \mathrm{~F}$

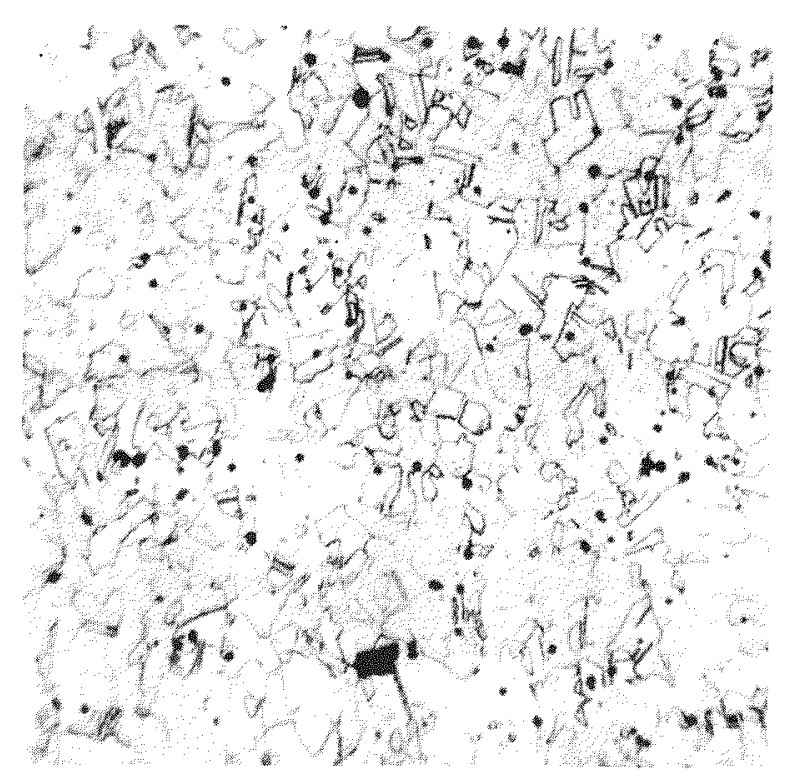

Etched

HC10168

b. Irradiated to $6.9 \times 10^{21} \mathrm{NVT}$

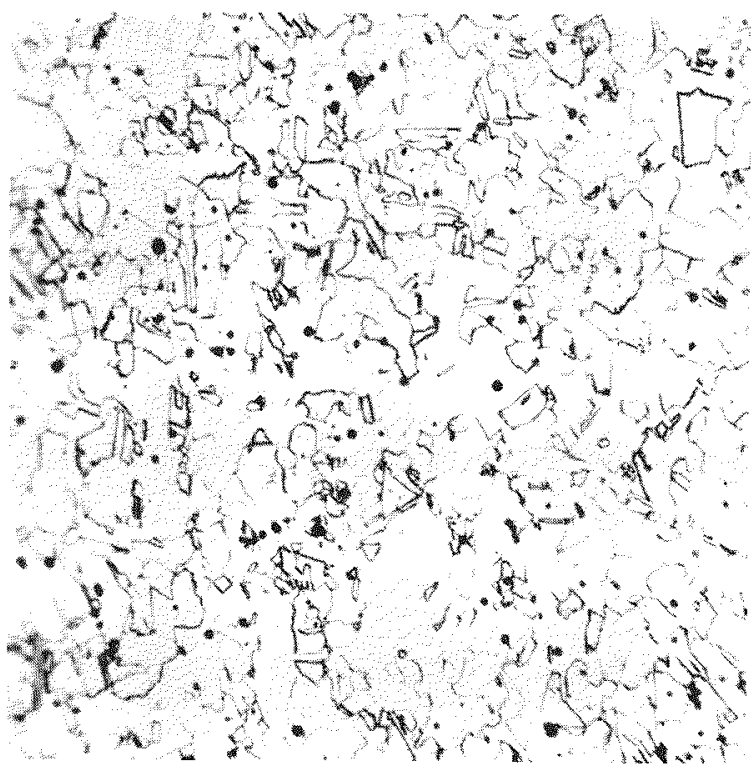

$200 \mathrm{x}$

Etched

HC10189

d. Irradiated to $6.5 \times 10^{21} \mathrm{NVT}$ and Annealed $1 \mathrm{Hr}$ at $1800 \mathrm{~F}$

FIGURE 8. MICROSTRUCTURES OF CONTROL AND IRRADIATED AISI TYPE 347 STAINLESS STEEL SPECIMENS FROM THE J -10 PRESSURE TUBE 


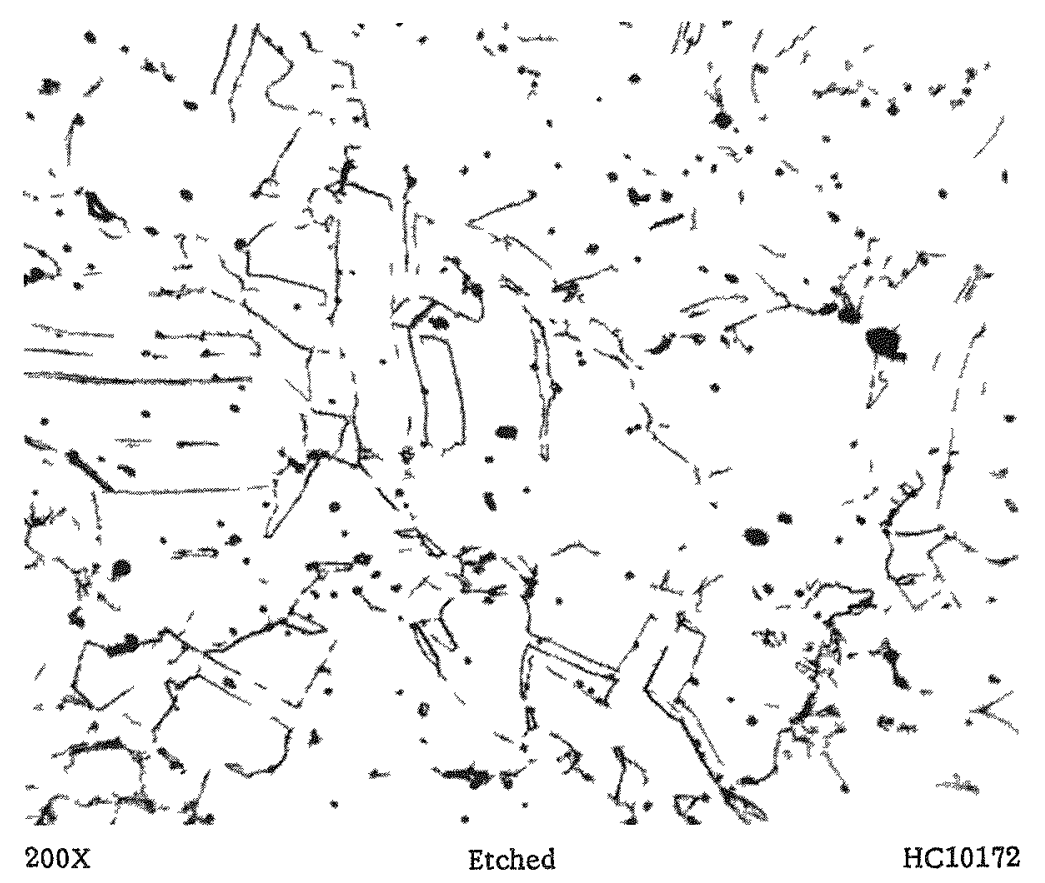

a. Specimen Given a Postirradiation Anneal for $1 \mathrm{hr}$ at Some Unknown Elevated Temperature

Temperature was not known because $R . F$. feedback into recorder gave faulty reading. Note the large grain size.

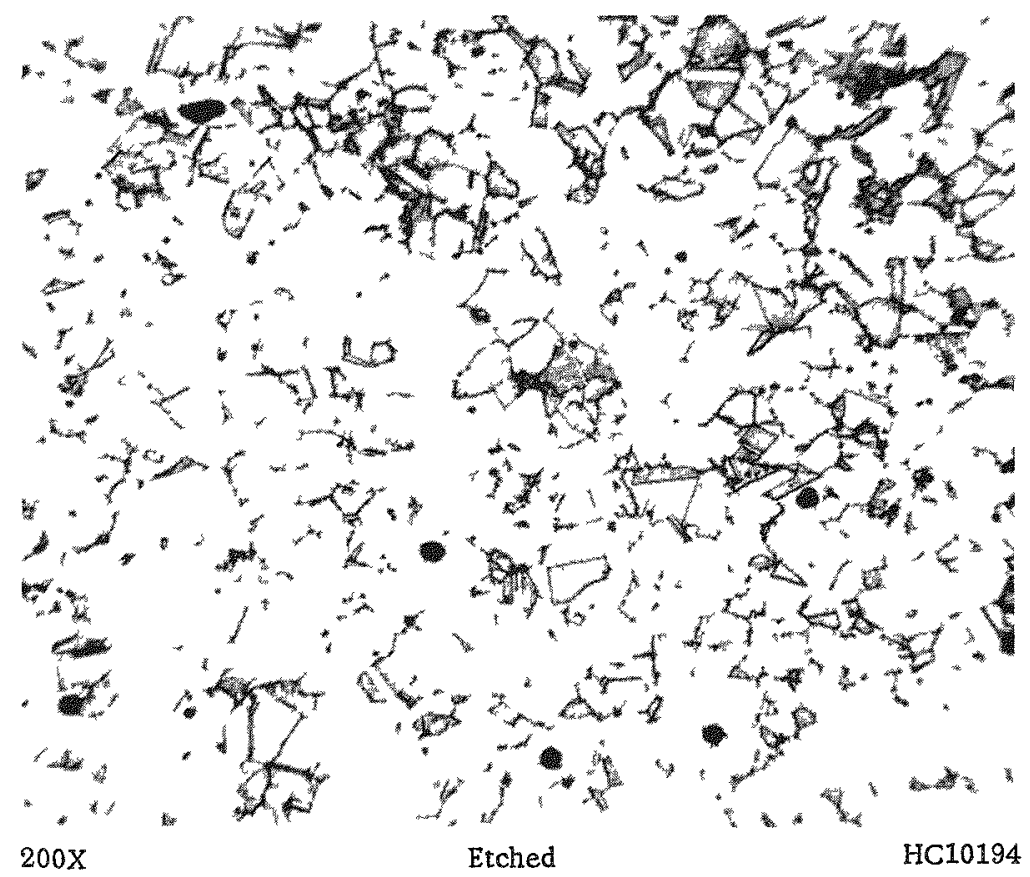

b. Specimen Inadvertently Heated to $1960 \mathrm{~F}$

Note the general rounding of grains, and the presence of grain-boundary precipitates. 
(5) The microstructure of the irradiated Type 347 stainless steel was not appreciably changed by $1-\mathrm{hr}$ anneals at 1000 or $1800 \mathrm{~F}$. In addition, the microstructure of as-irradiated Type 347 stainless steel as determined through routine hot-cell metallographic examinations was similar to that of unirradiated control samples.

Exceptions to the above were noted in two cases of irradiated samples that were inadvertently heated above $1800 \mathrm{~F}$. These samples underwent grain growth, and one contained a grain-boundary precipitate which looked similar to that present in sensitized Type 304 stainless steel.

The results of the program indicate that the recovery of the mechanical properties of irradiated Type 347 stainless steel to approch those of the unirradiated material can be accomplished by $1-\mathrm{hr}$ anneals at 1000 or $1800 \mathrm{~F}$. Although nearly complete recovery of preirradiation properties occurs upon annealing at these temperatures, there have been no data on the effects of subsequent irradiation upon annealed specimens.

\section{ACKNOWLEDGMENTS}

The authors with to thank Dr. E. S. Byron and C. D. Sellers of the Bettis Atomic Power Laboratory for their continuing assistance throughout the course of this investigation.

\section{REFERENCES}

(1) Murr, W.E., Shober, F. R., Lieberman, R., and Dickerson, R. F., "Effects of Large Neutron Doses and Elevated Temperature on Type 347 Stainless", BMI-1609 (January 21, 1963).

(2) Bailey, R. E., and Silliman, M. A., "Effects of Irradiation on the Type 347 Stainless Steel Flow Separator in the EBR-1 Core", Symposium on Radiation Effects on Materials, Vol 3, ASTM-STP-233 (1958), p 84.

WEM/FRS:mjd 
APPENDIX

FRACTURE ZONES OF SPECIMENS TESTED 


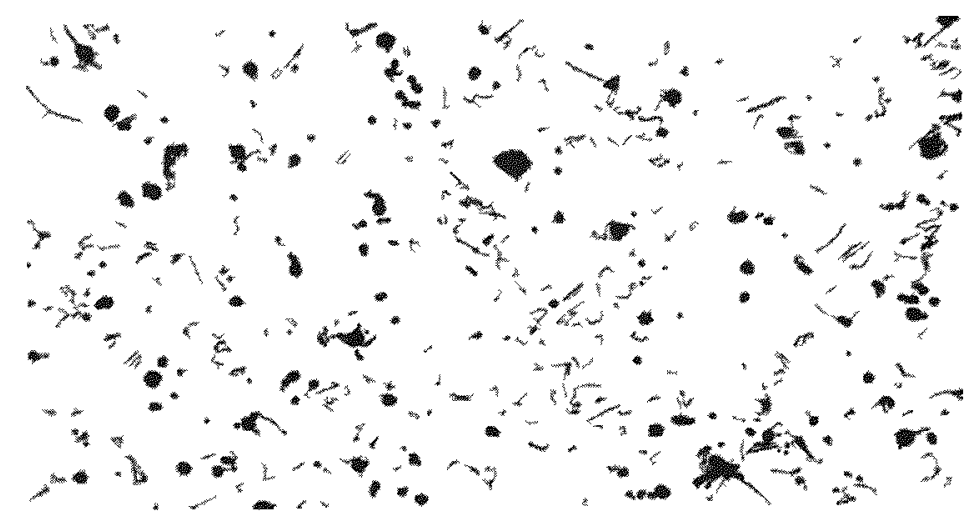

$200 \mathrm{X}$

Microstructure

HC10164

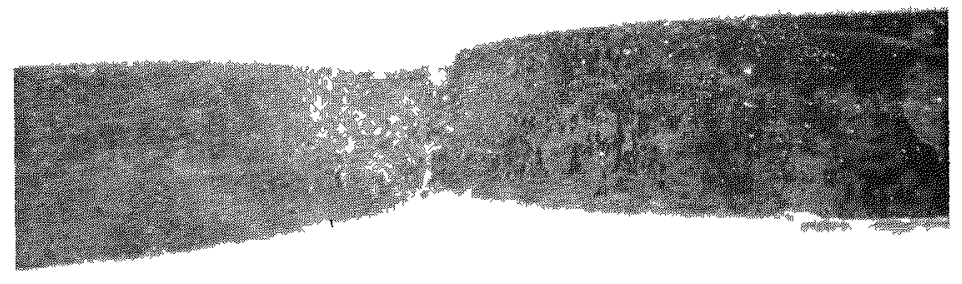

$4 X$

HC10074

Edge

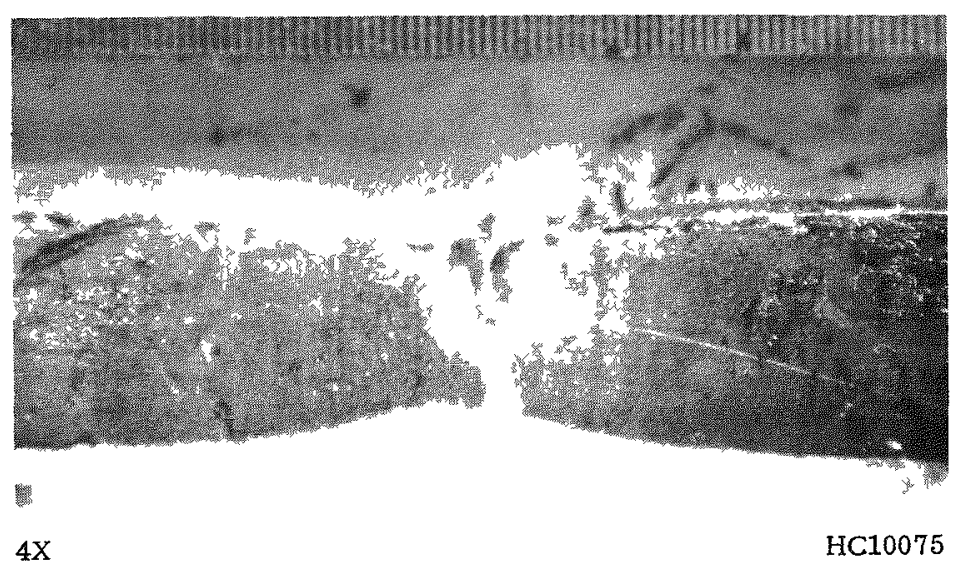

Flat

FIGURE A-1. FRACTURE ZONE AND MICROSTRUCTURE OF SPECIMEN ST -7-L AFTER TESTING AT $75 \mathrm{~F}$ No heat treatment was employed before testing. 


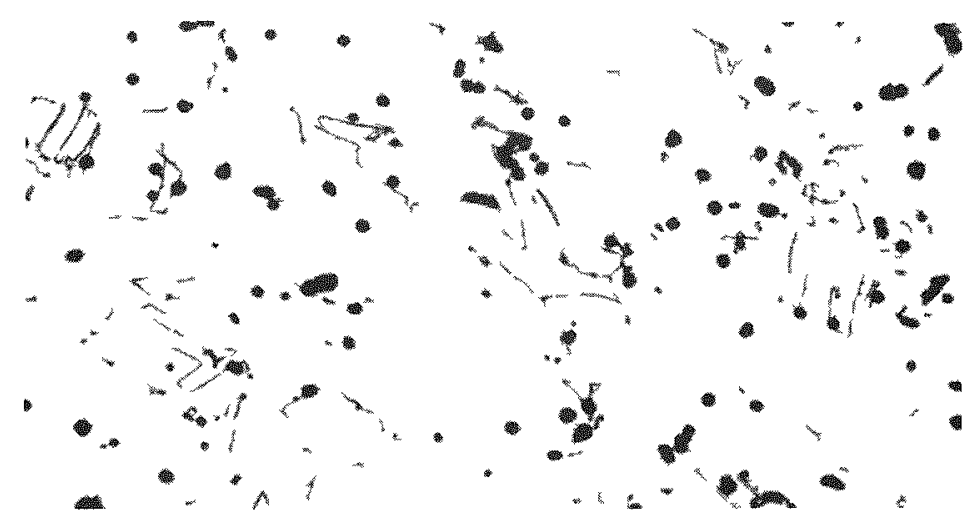

$200 \mathrm{X}$

Microstructure

HC10156
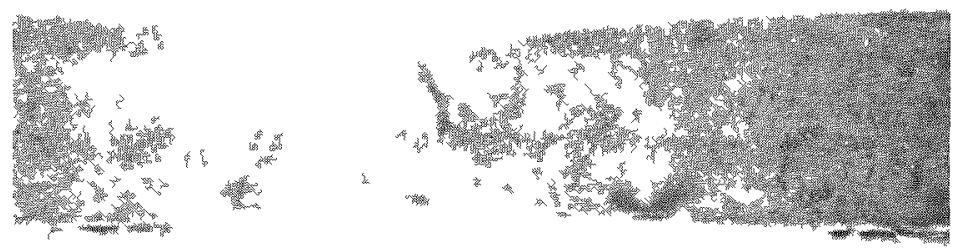

$4 X$

HC10068

Edge
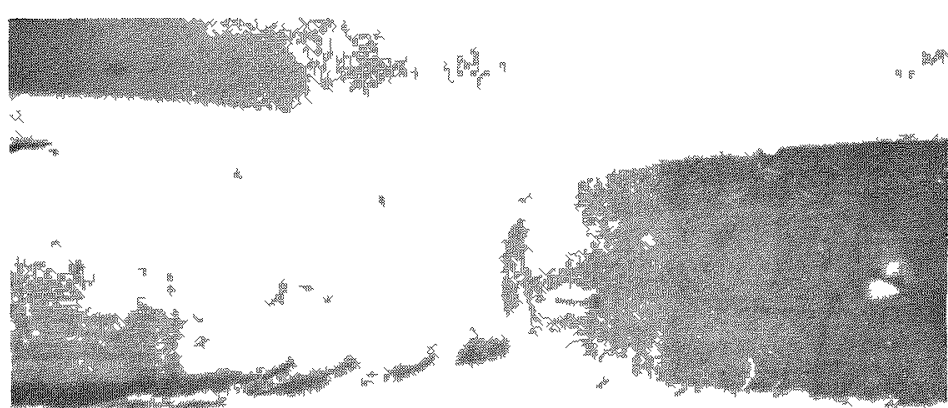

$4 X$

HC10069

Flat 


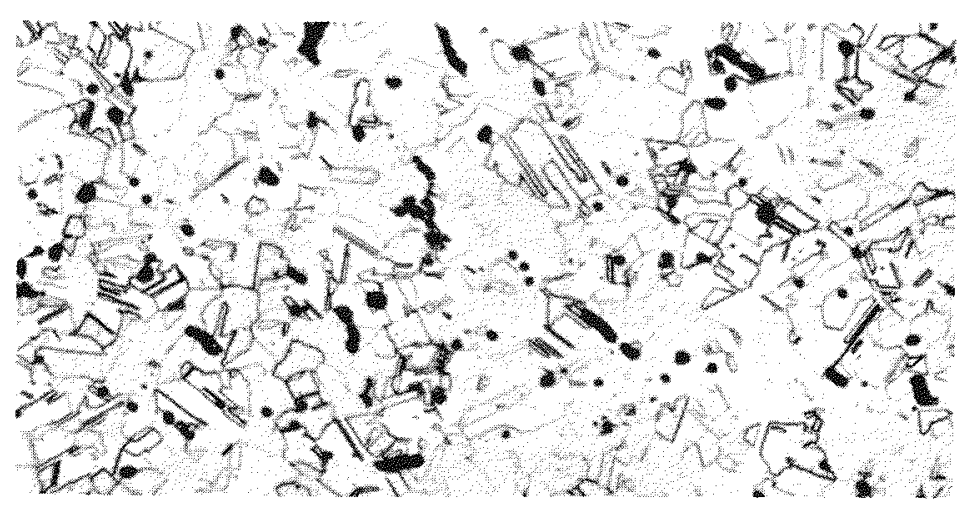

$200 x$

HC10161

Microstructure

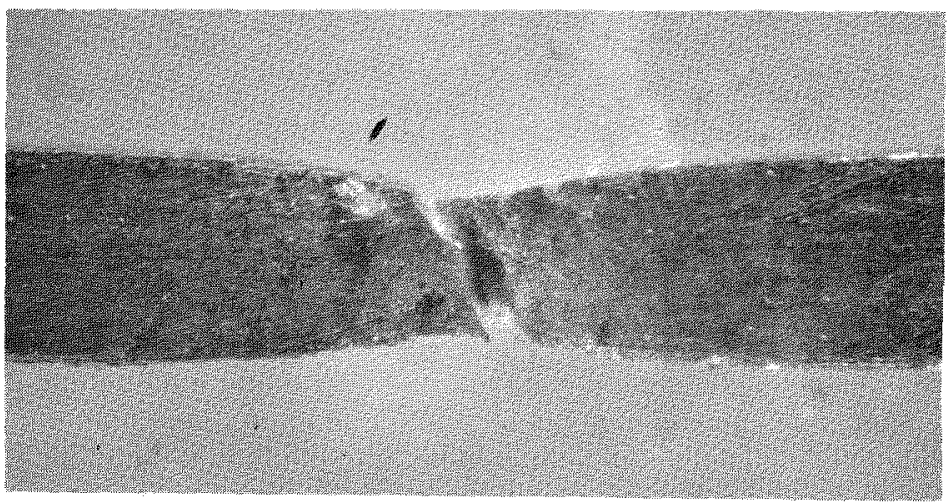

$4 X$

HC10071

Edge

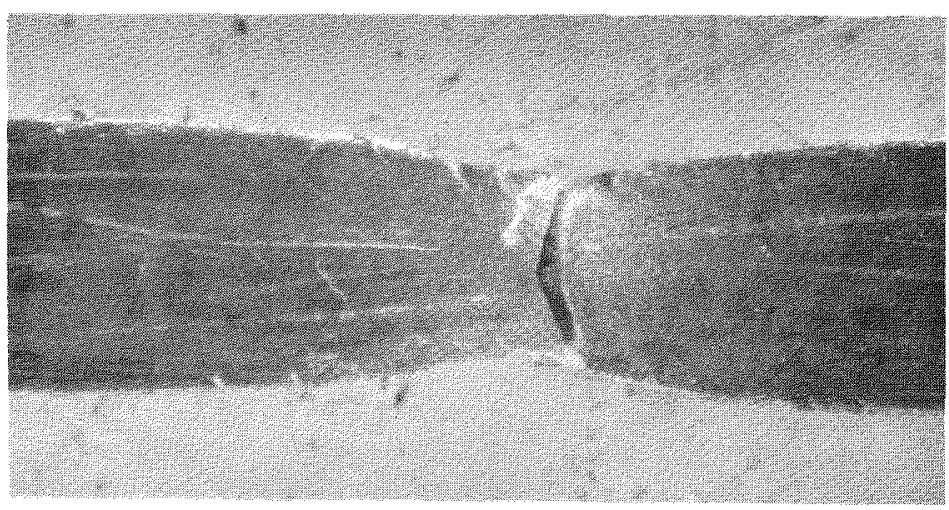

$4 X$

$\mathrm{HC} 10072$

Flat

FIGURE A-3. FRACTURE ZONE AND MICROSTRUCTURE OF SPECIMEN ST-7-1 AFTER TESTING AT $75 \mathrm{~F}$ No heat treatment was employed before testing. 


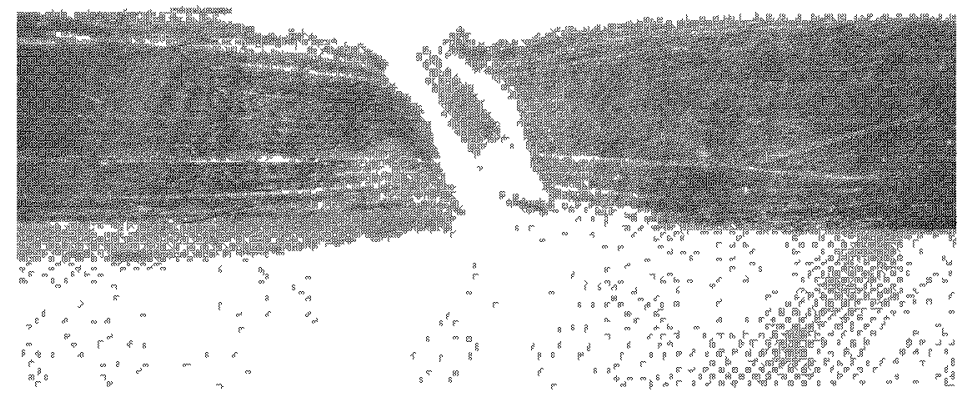

$4 \mathrm{X}$

HC10092

Edge

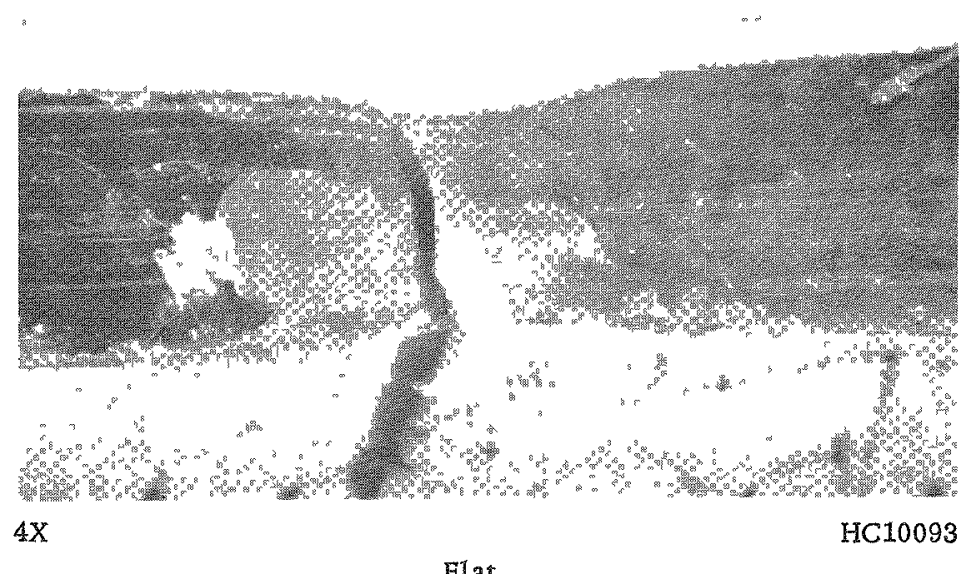

Flat

FIGURE A 4 . FRACTURE ZONE OF SPECIMEN SB-7-I AFTER TESTING AT $750 \mathrm{~F}$ No heat treatment was employed before testing. 


\section{$A-5$}

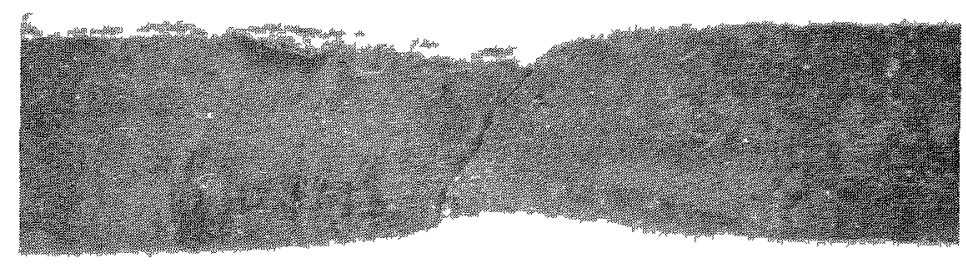

$4 \mathrm{X}$

HC10089

Edge

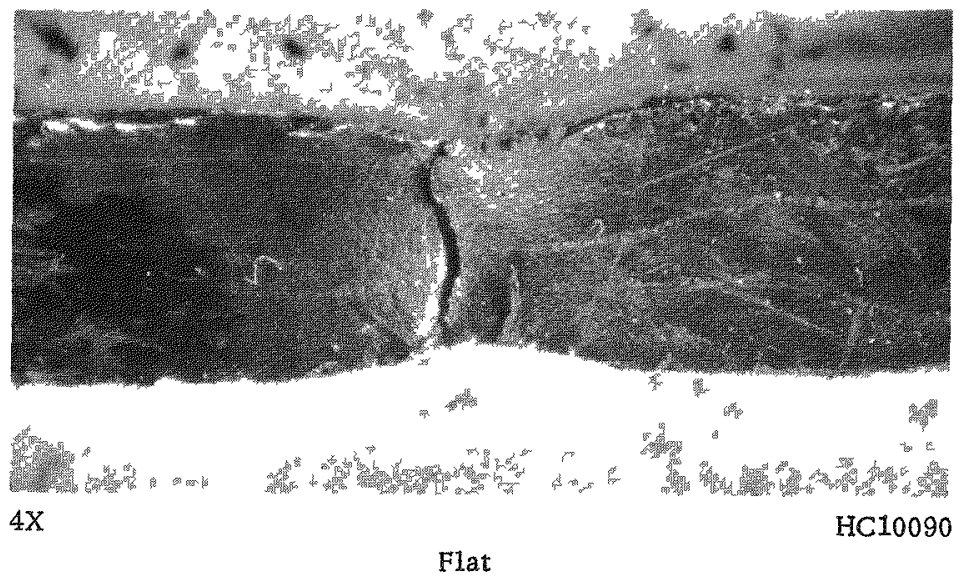

FIGURE A -5. FRACTURE ZONE OF SPECIMEN SB -7-L AFTER TESTING AT $750 \mathrm{~F}$

No heat treatment was employed before testing. 

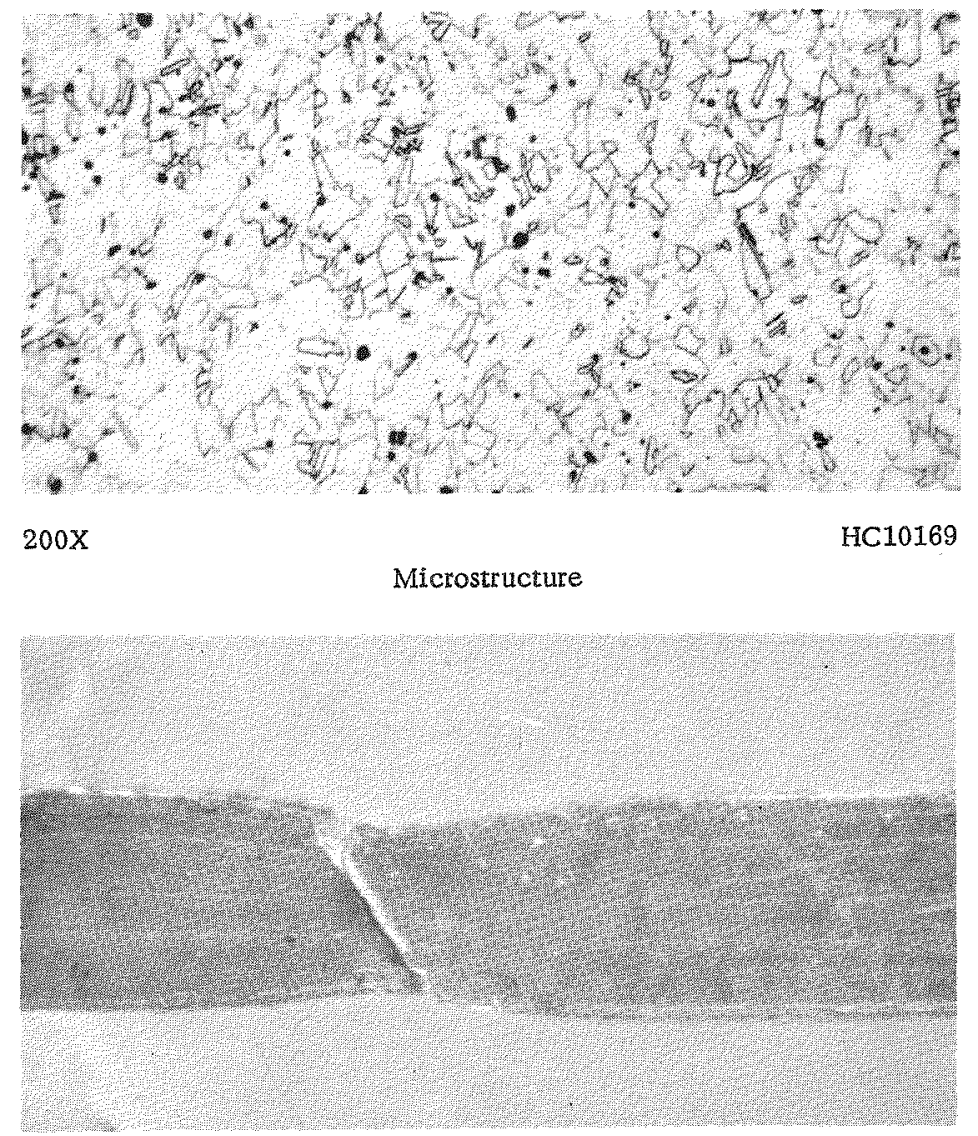

$4 \mathrm{X}$

HC10095

Edge

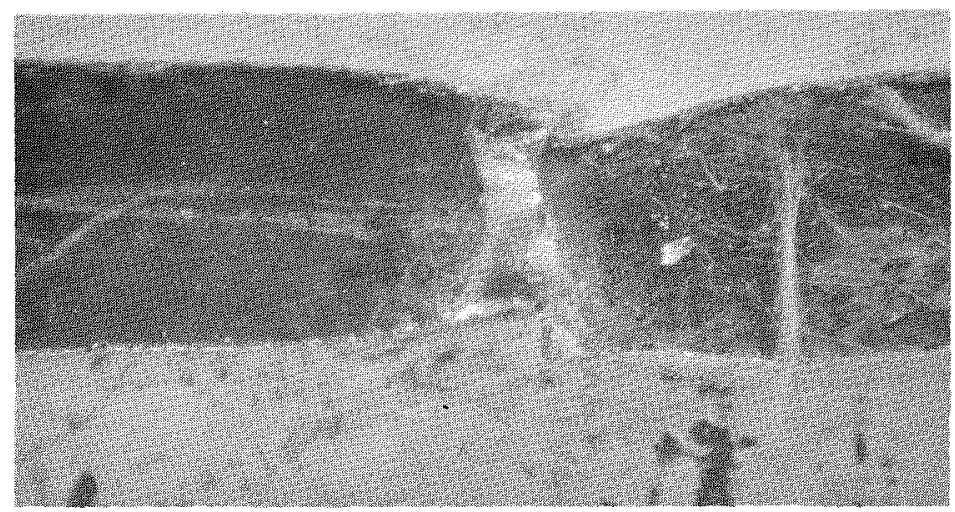

$4 \mathrm{X}$

HC10096

Fiat 


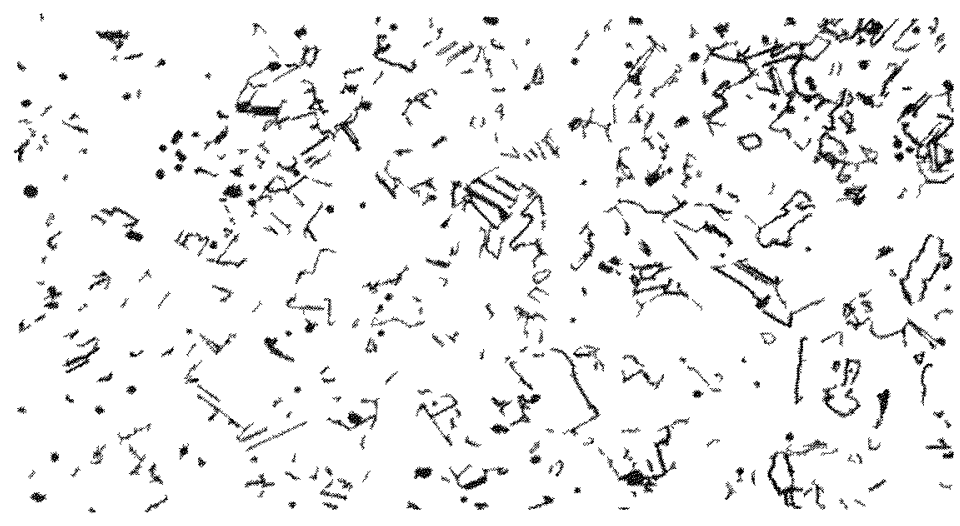

$200 x$

Microstructure

HC10186

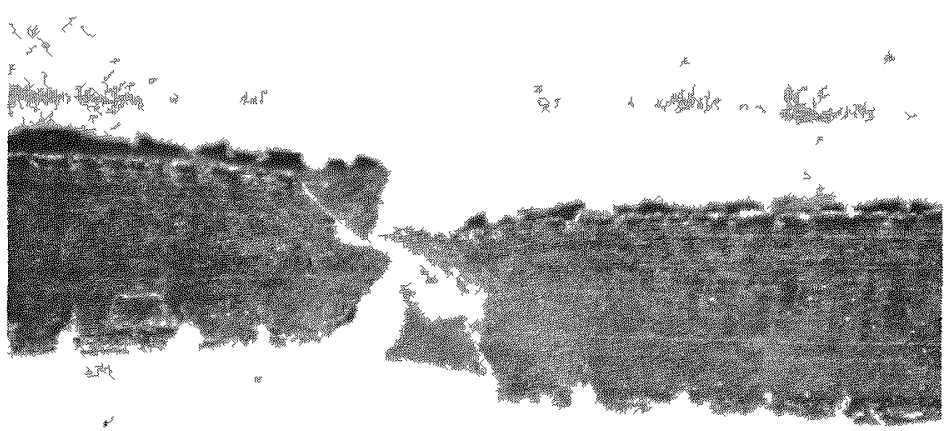

$4 X$

HC10115

Edge

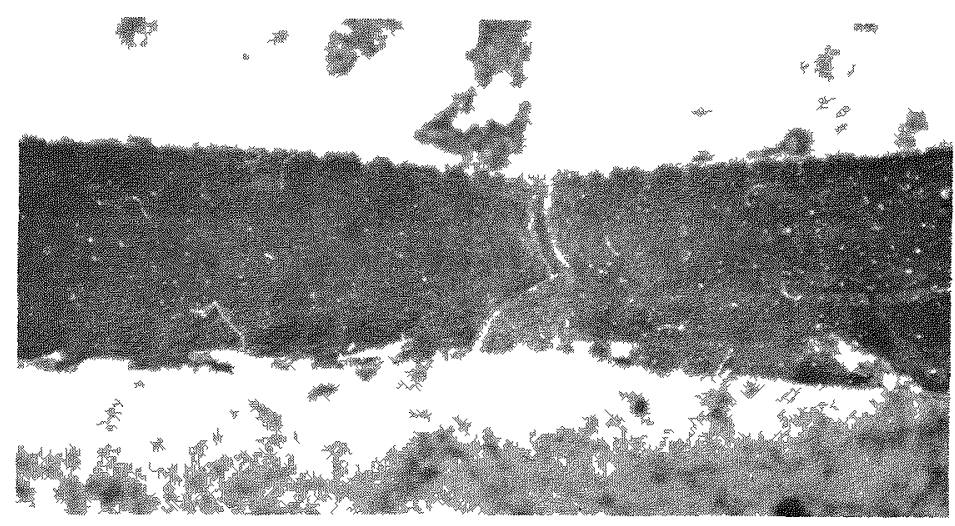

$4 X$

HC10114

Flat

FIGURE A -7. FRACTURE ZONE AND MICROSTRUCTURE OF SPECIMEN ST -3-I AFTER TESTING AT 75 F

This specimen was annealed at $1800 \mathrm{~F}$ for $1 \mathrm{hr}$ before testung. The temperature went to $1930 \mathrm{~F}$ for $2 \mathrm{~min}$ and then decreased to $1800 \mathrm{~F}$ in about 6 min during the annealing treatment. 


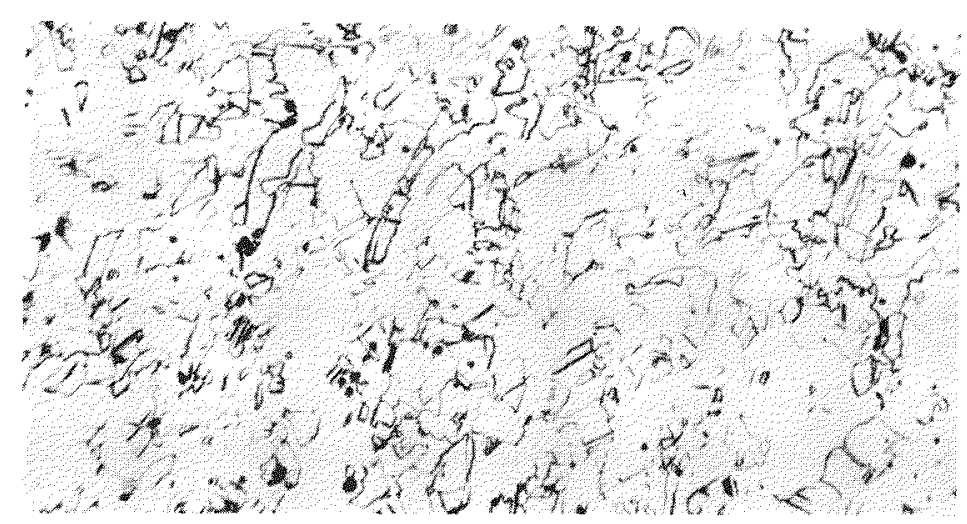

$200 \mathrm{X}$

\section{Microstructure}

HC10190

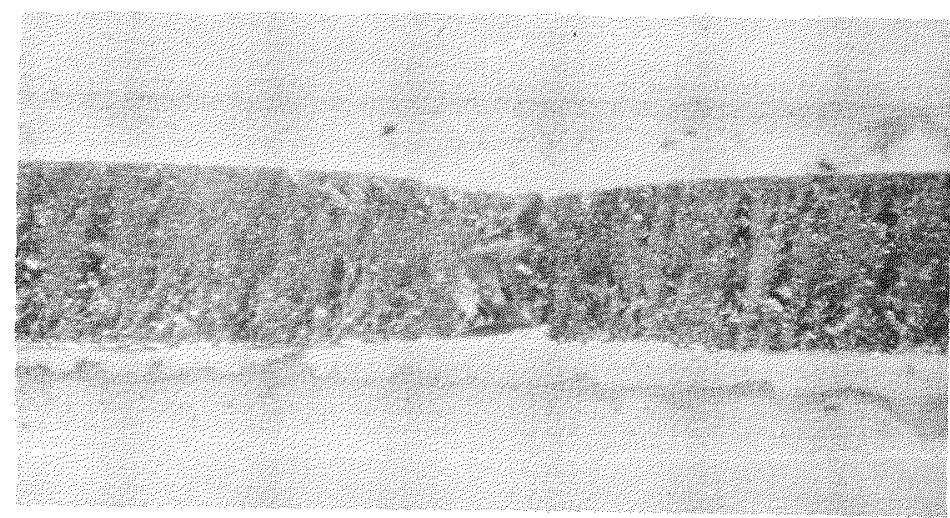

$4 X$

HC10121

Edge

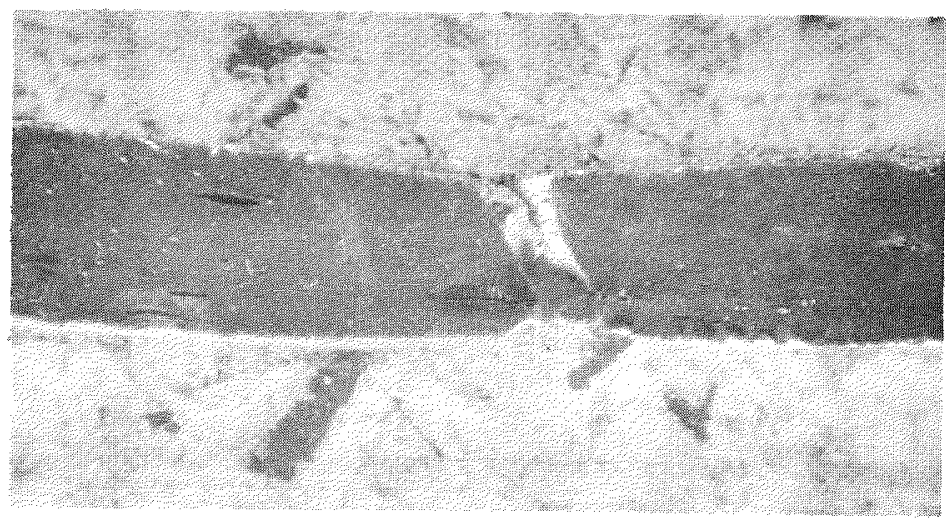

$4 X$

Flat

HC10120

FIGURE A -8. FRACTURE ZONE AND MICROSTRUCTURE OF SPECIMEN SB -3 -H AFTER TESTING AT 75 F This specimen was annealed at $1800 \mathrm{~F}$ for $1 \mathrm{hr}$ before testing. 
A-9
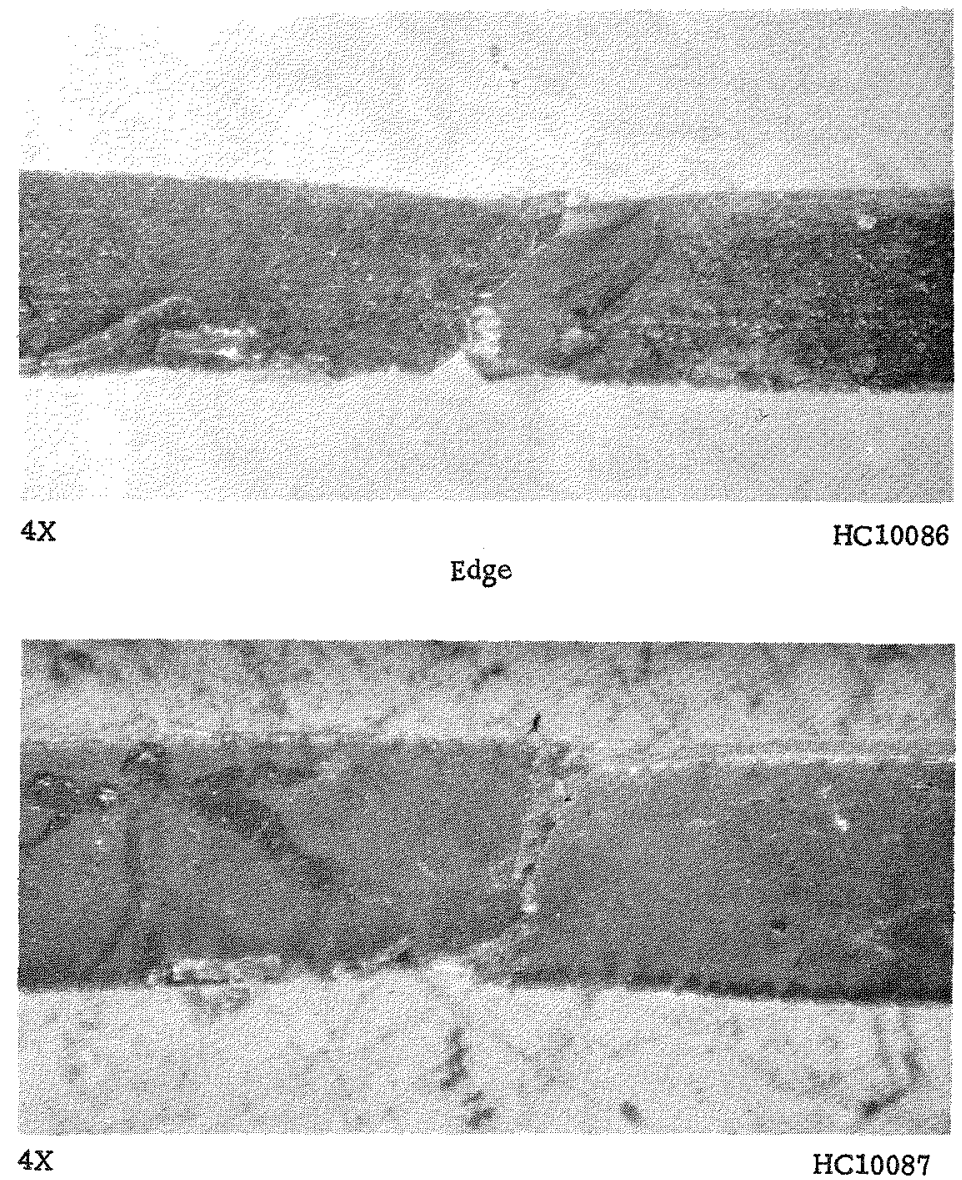

Flat

FIGURE A -9. FRACTURE ZONE OF SPECIMEN SB $-6-\mathrm{H}$ AFTER TESTING AT $750 \mathrm{~F}$

This specimen was annealed at $1800 \mathrm{~F}$ for $1 \mathrm{hr}$ before testing. 


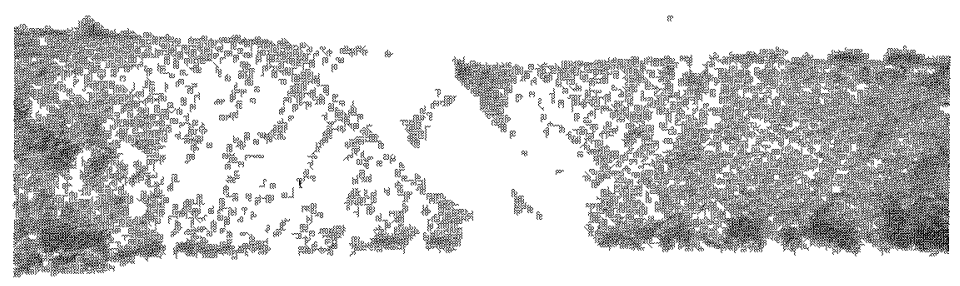

$4 X$

$\mathrm{HC} 10083$

Edge

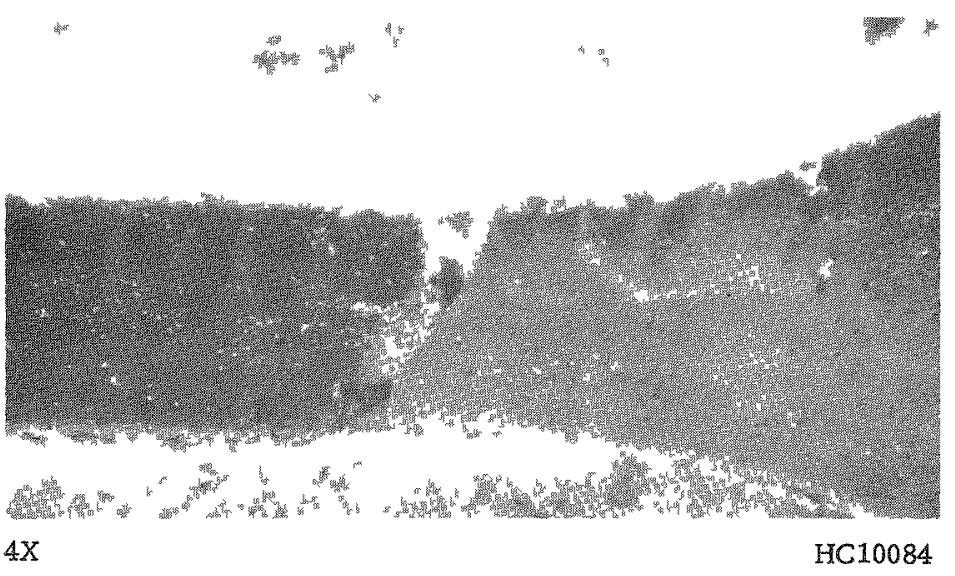

Flat

FIGURE A-10. FRACTURE ZONE OF SPECIMEN SB $\approx 6$ m AFTER TESTING AT $75 \mathrm{~F}$

This specumen was annealed at $1800 \mathrm{~F}$ for 1 hr before testing. 


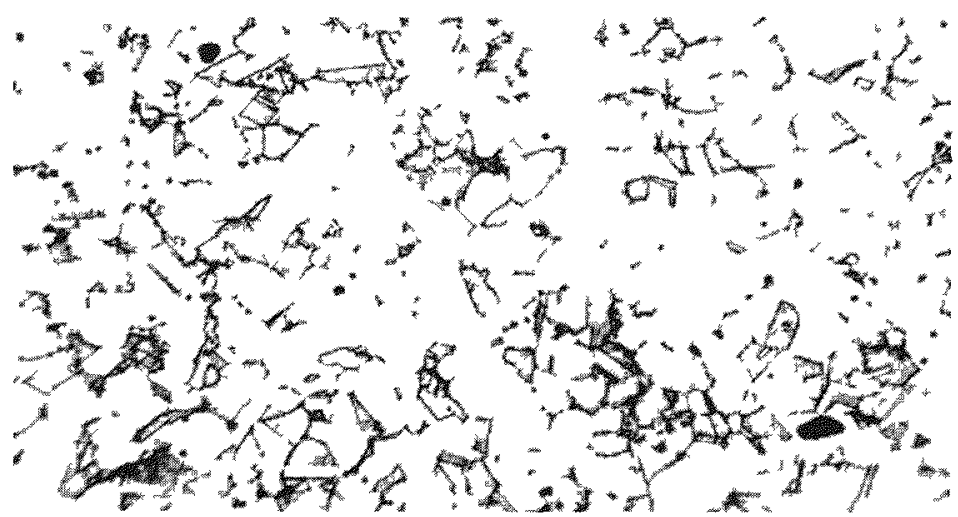

HC10194

Microstructure

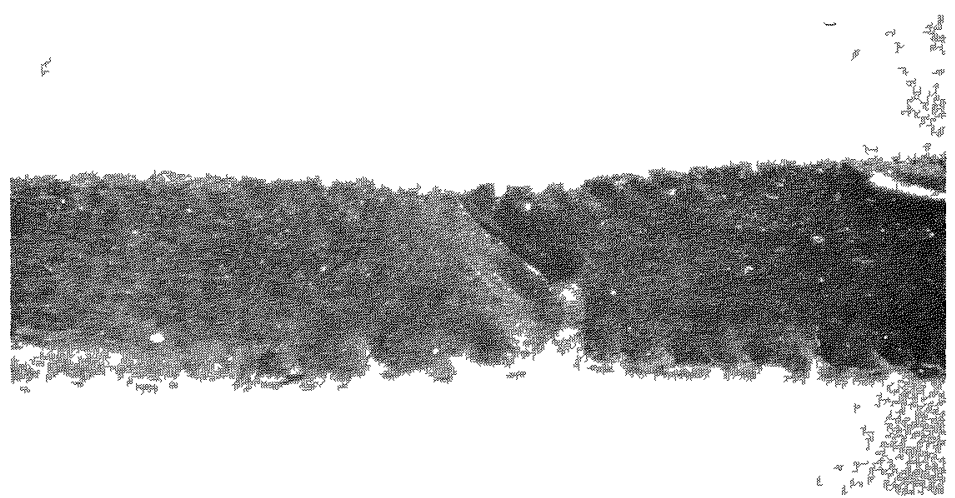

$4 X$

HC10065

Edge

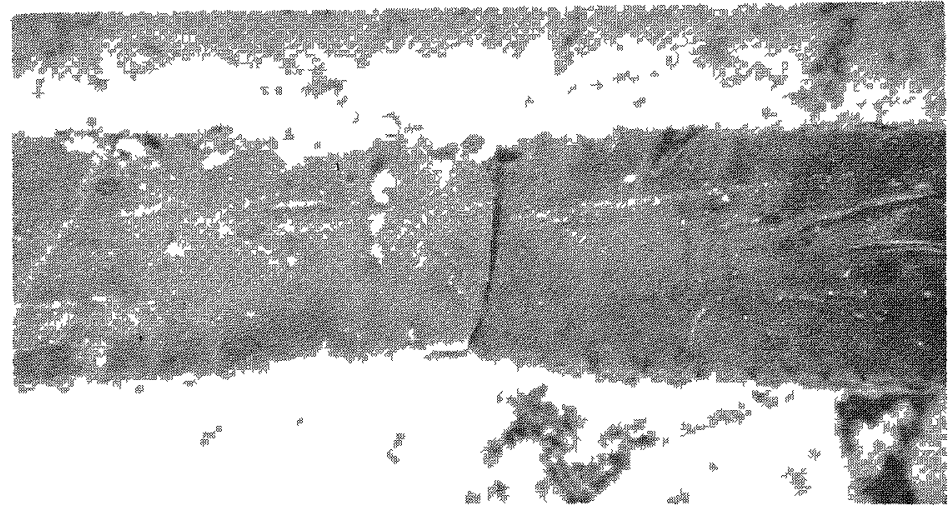

$4 X$

HC10066

Flat

FIGURE A $=11$. FRACTURE ZONE AND MICROSTRUCTURE OF SPECIMEN ST $-6 \sim$ L AFTER TESTING A T $750 \mathrm{~F}$

This specimen was annealed at $1800 \mathrm{~F}$ for $1 \mathrm{hr}$ before testing. The temperature went to $1950 \mathrm{~F}$ for $3 \mathrm{~min}$ and then decreased to $1800 \mathrm{~F}$ in about $7 \mathrm{~min}$ during the annealing treatment. 


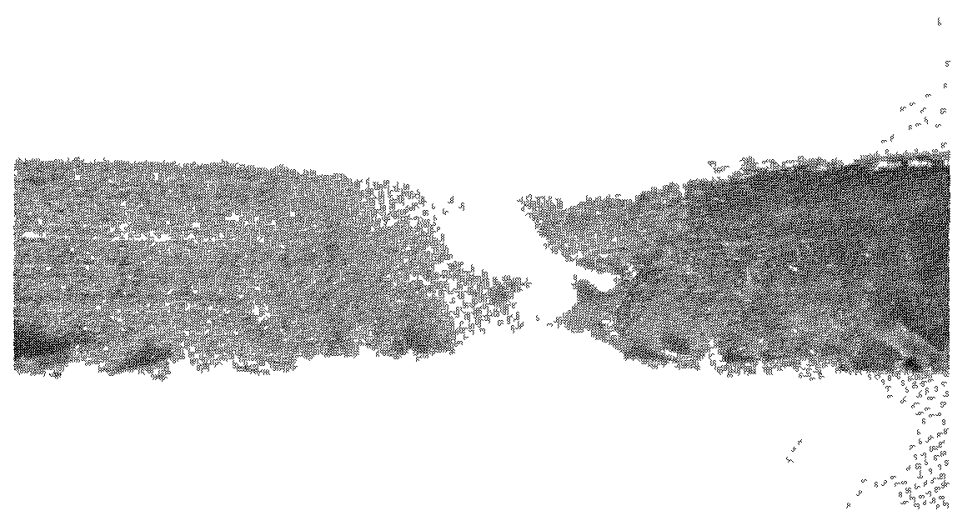

$4 X$

HC 10063

Edge

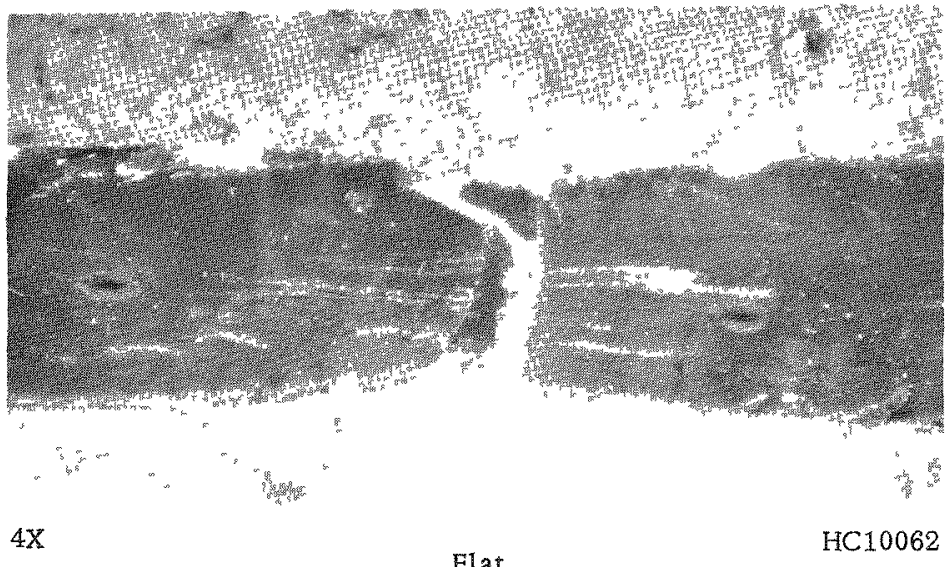

FIGURE A-12. FRACTURE ZONE OF SPECIMEN ST-6-I AFTER TESTING AT 750 F This specimen was annealed at $1800 \mathrm{~F}$ for $1 \mathrm{hr}$ before testing. 

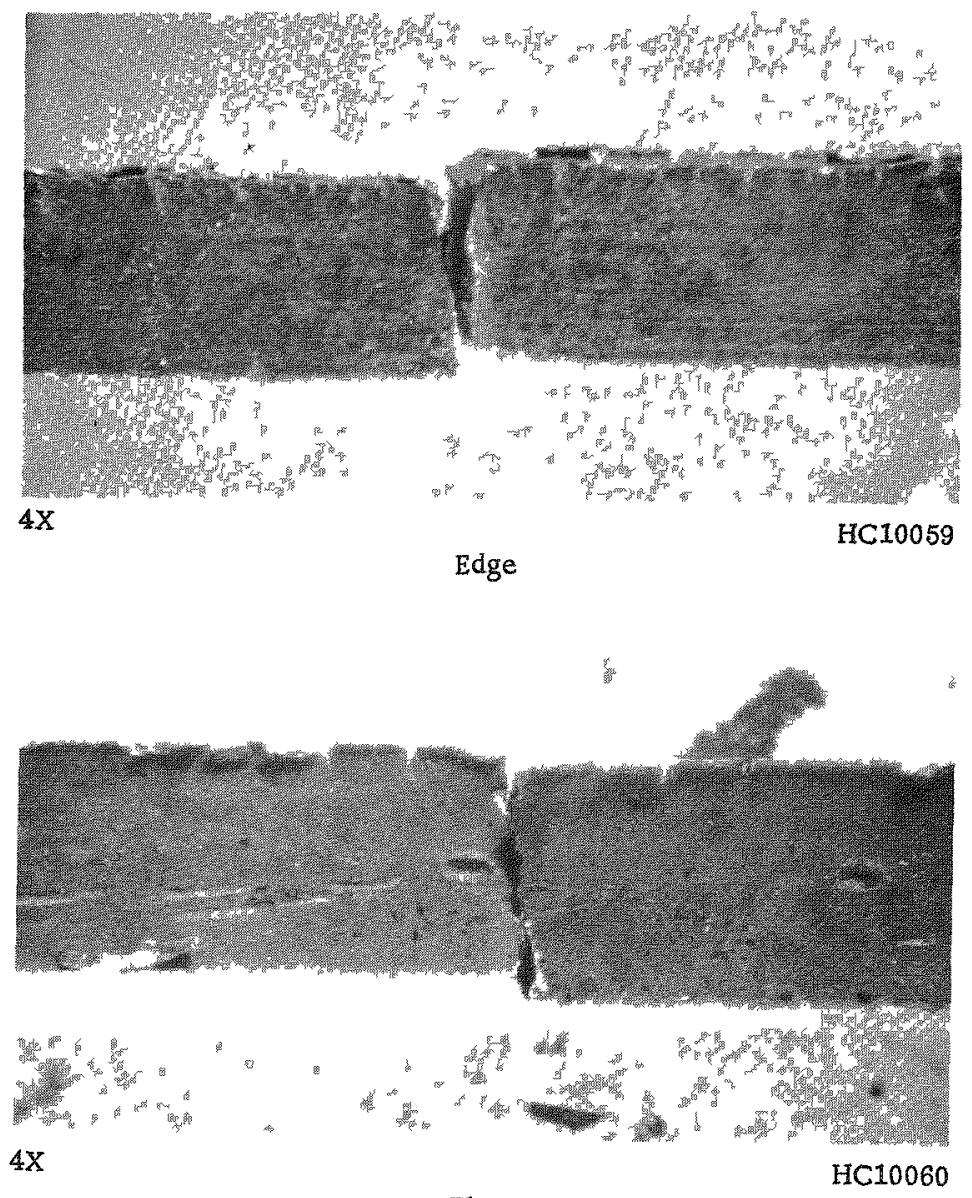

Flat

FIGURE A-13. FRACTURE ZONE OF SPECIMEN ST-6-H AFTER TESTING AT 75 F This specimen was annealed at $1800 \mathrm{~F}$ for $1 \mathrm{hr}$ before the test. 


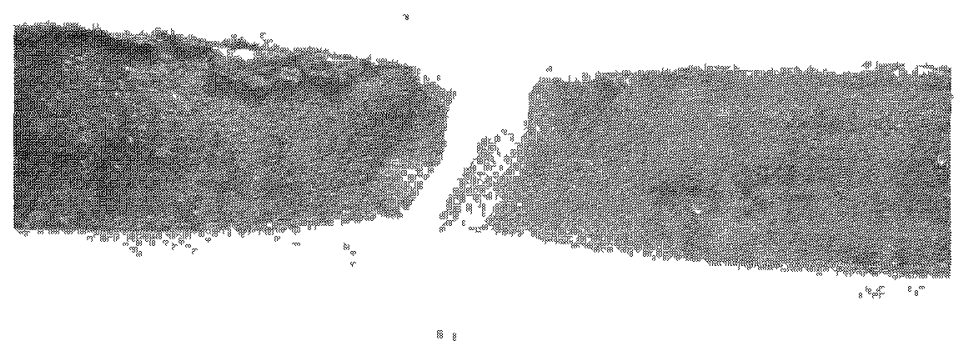

$4 X$

HC10098

Edge

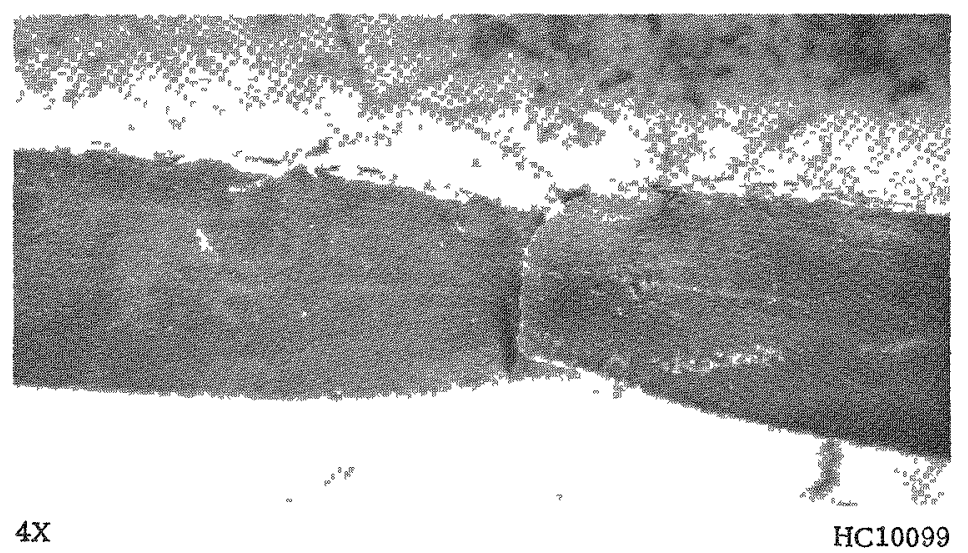

Filat

FIGURE A -14. FRACTURE ZONE OF SPECIMEN ST -4-H AFTER TESTING AT 750 F This specimen was annealed at $1800 \mathrm{~F}$ for $1 \mathrm{hr}$ before testing. 


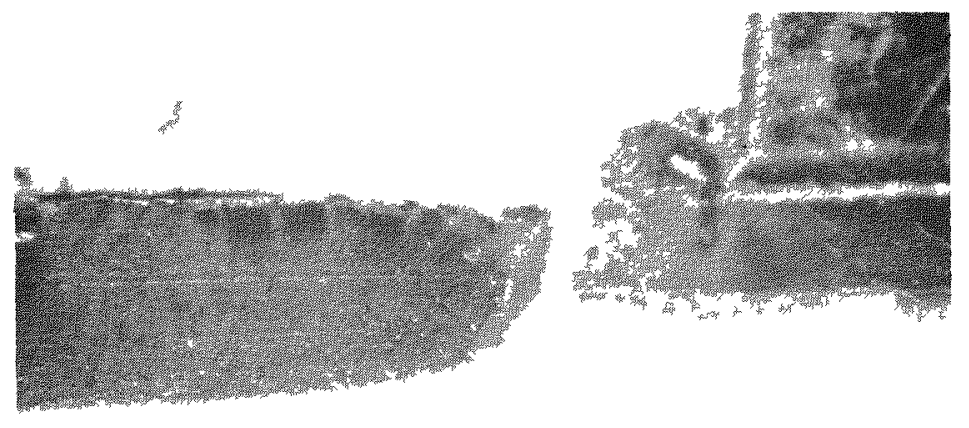

$4 X$

HC10106

Edge

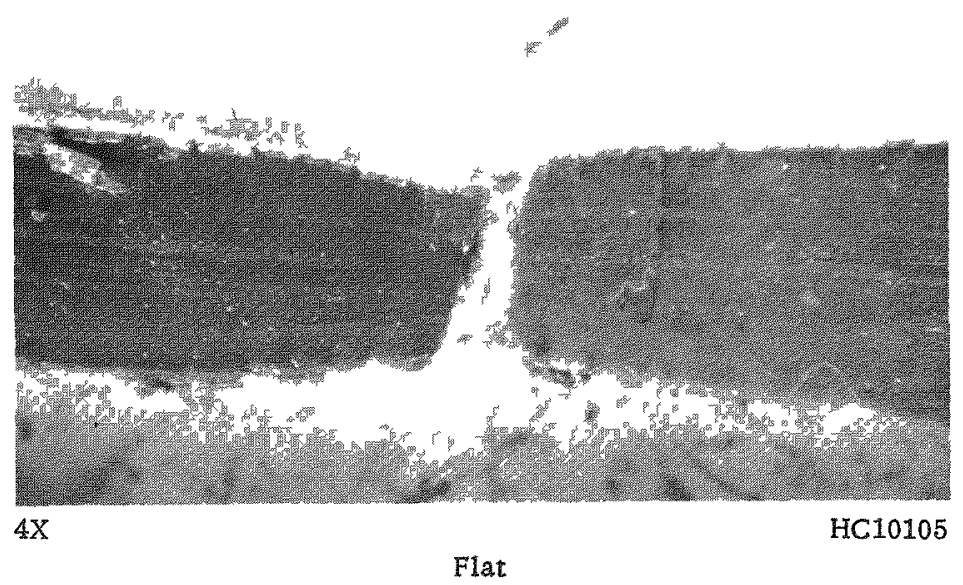

FIGURE A-15. FRACTURE ZONE OF SPECIMEN SB $-4-I$ AFTER TESTING AT $750 \mathrm{~F}$ This specmen was annealed at $1800 \mathrm{~F}$ for $1 \mathrm{hr}$ before testing. 


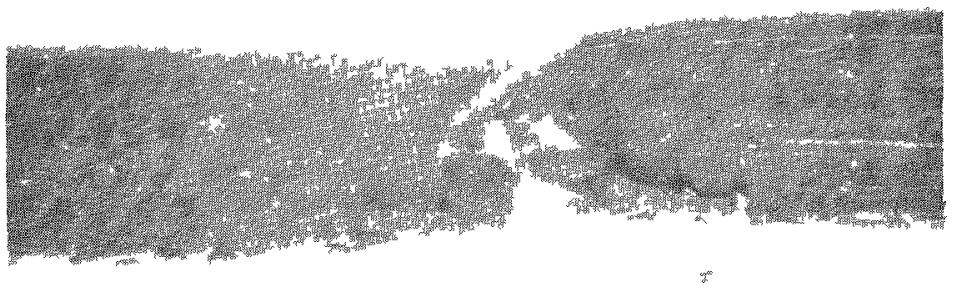

$4 \mathrm{X}$

HC10117

Edge

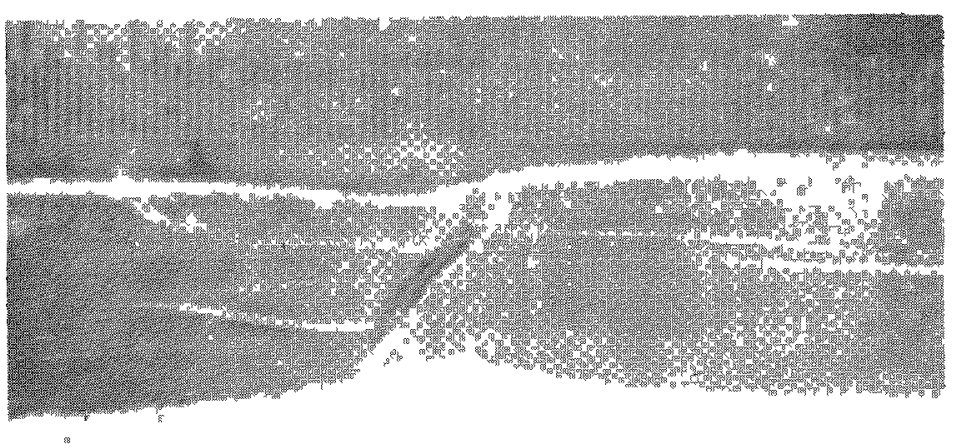

$4 \mathrm{X}$

HC10118

Flat

FIGURE A-16. FRACTURE ZONE OF SPECIMEN SB-3-I AFTER TESTING AT $750 \mathrm{~F}$

This spectmen was annealed at $1000 \mathrm{~F}$ for $1 \mathrm{hr}$ before testing. 


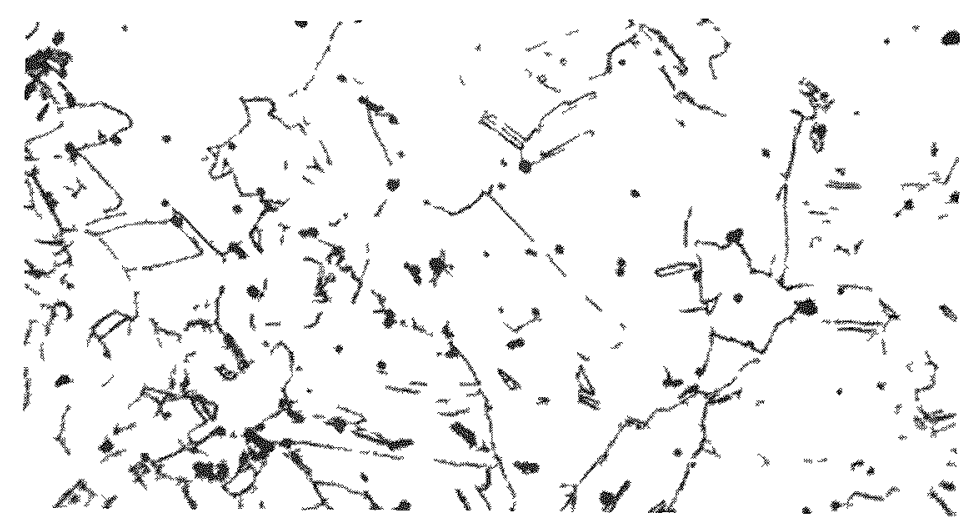

$200 x$

HC10173

Microstructure

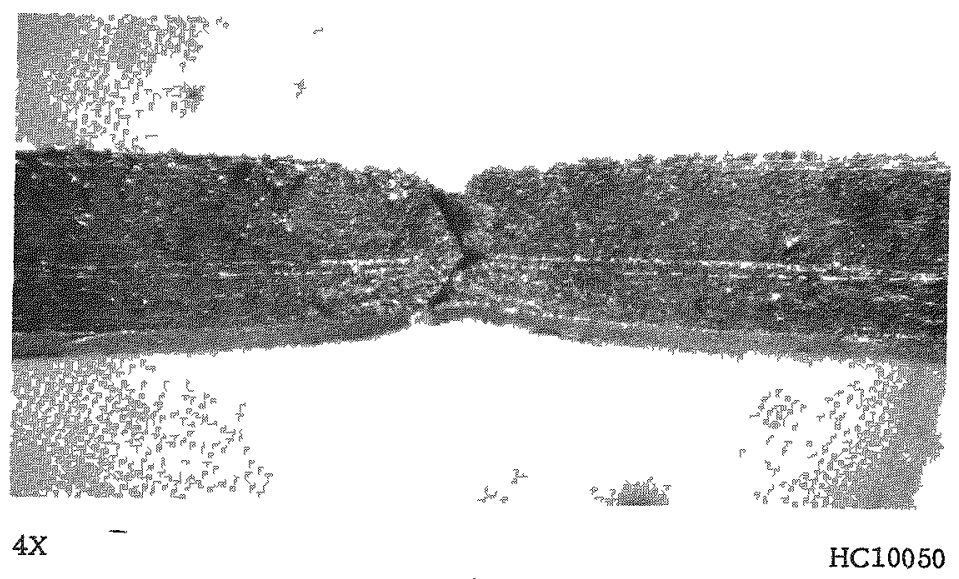

Edge

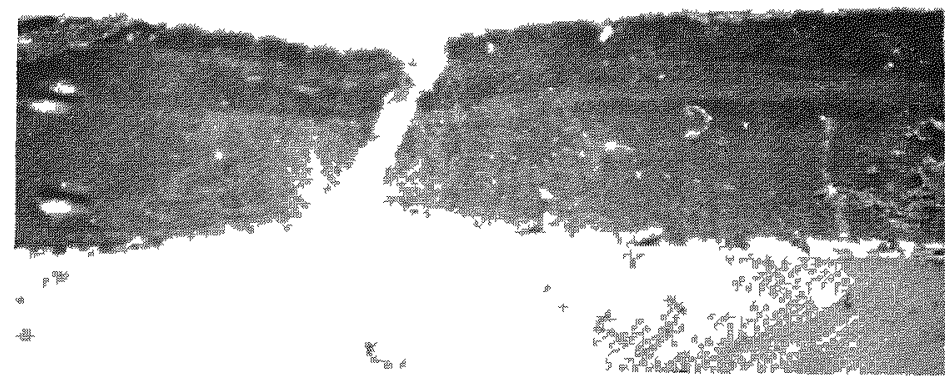

$4 X$

HC10051

Flat

FIGURE A-17. FRACTURE ZONE AND MICROSTRUCTURE OF SPECIMEN ST $-5-H$ AFTER TESTING AT 75 F This specimen was annealed at $1000 \mathrm{~F}$ for $1 \mathrm{hr}$ before testing. 


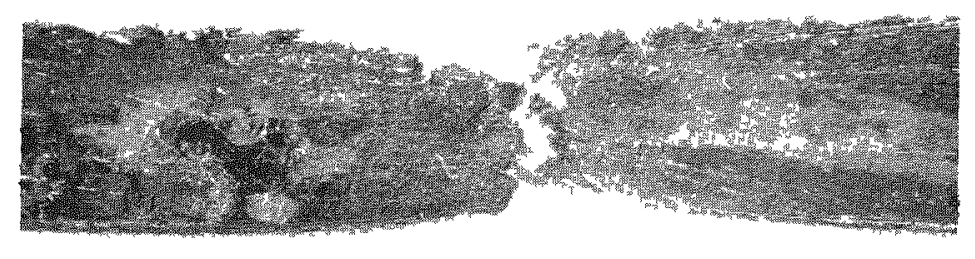

$4 X$

$\mathrm{HC} 10053$

Edge

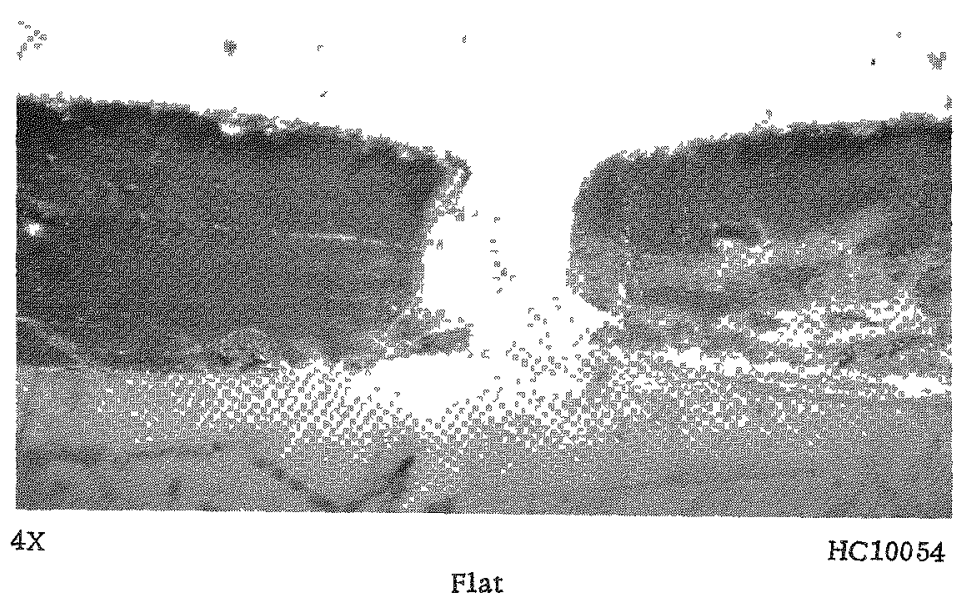

FIGURE A-18. FRACTURE ZONE OF SPECIMEN ST-5-I AFTER TESTING AT $750 \mathrm{~F}$ This specimen was annealed at $1000 \mathrm{~F}$ for $1 \mathrm{hr}$ before testing. 


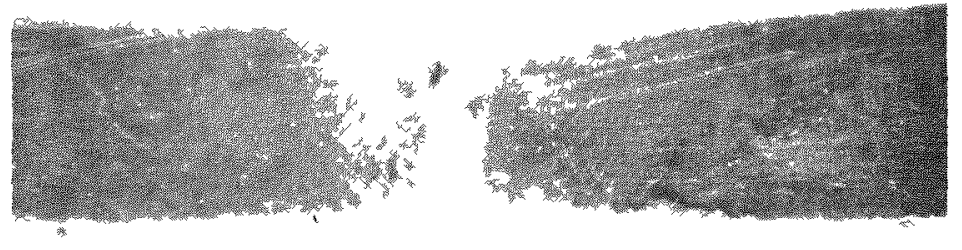

$4 X$

HC10080

Edge

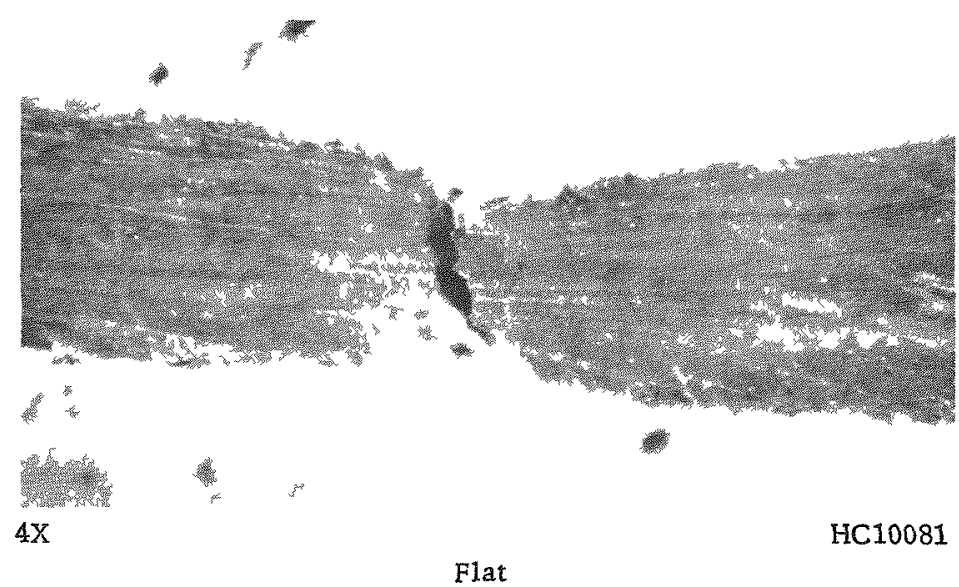

FIGURE A-19. FRACTURE ZONE OF SPECIMEN SB-5-H AFTER TESTING AT $750 \mathrm{~F}$ This specimen was annealed at $1000 \mathrm{~F}$ for $1 \mathrm{hr}$ before testing. 


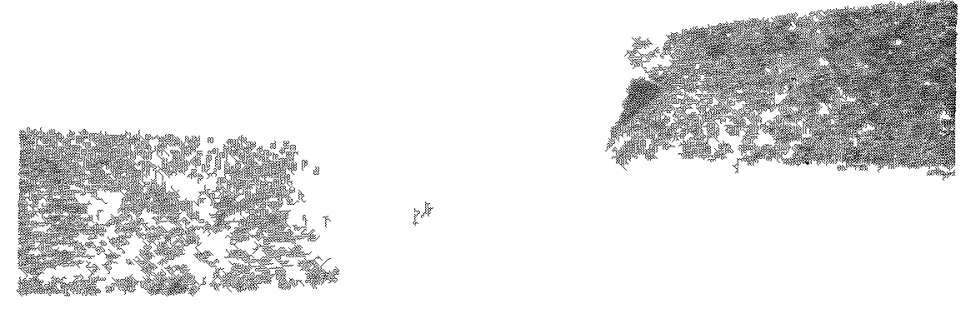

$4 \mathrm{X}$

HC10077

Edge

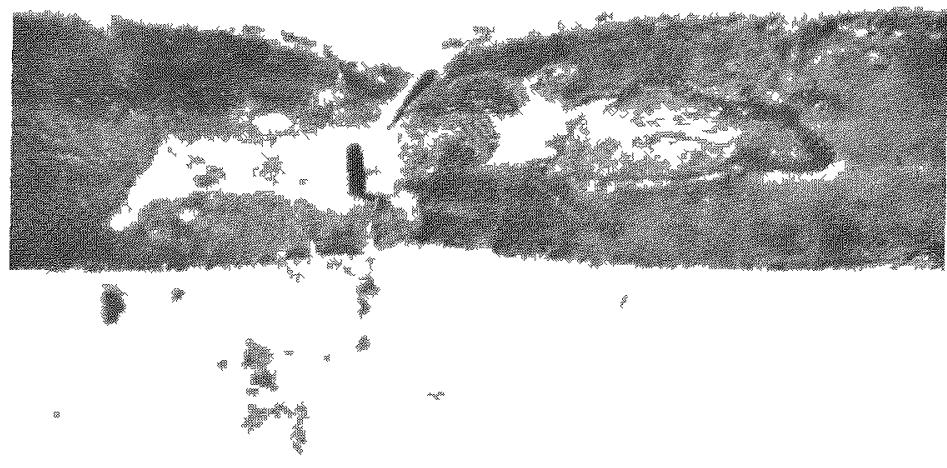

$4 X$

HC10078

Flat

FIGURE A-20. FRACTURE ZONE OF SPECIMEN SB-5-I AFTER TESTING AT 75 F

This specimen was annealed at $1000 \mathrm{~F}$ for $1 \mathrm{hr}$ before testing. 


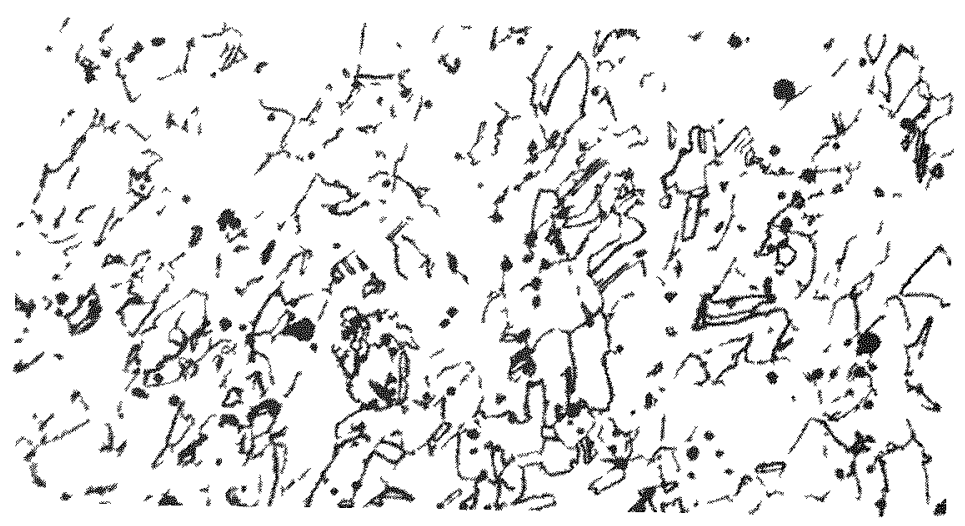
$200 x$

Microstructure

HC10176

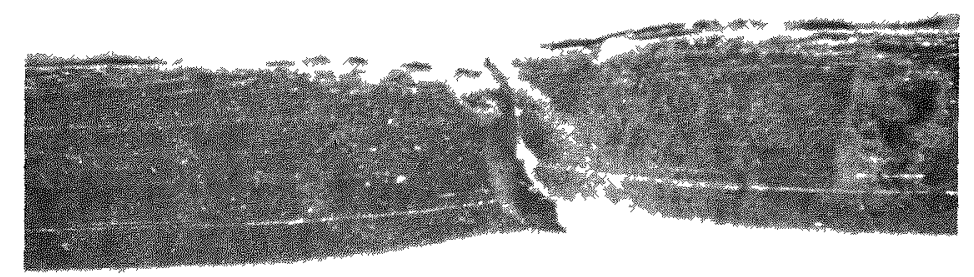

$4 X$

HC10056

Edge

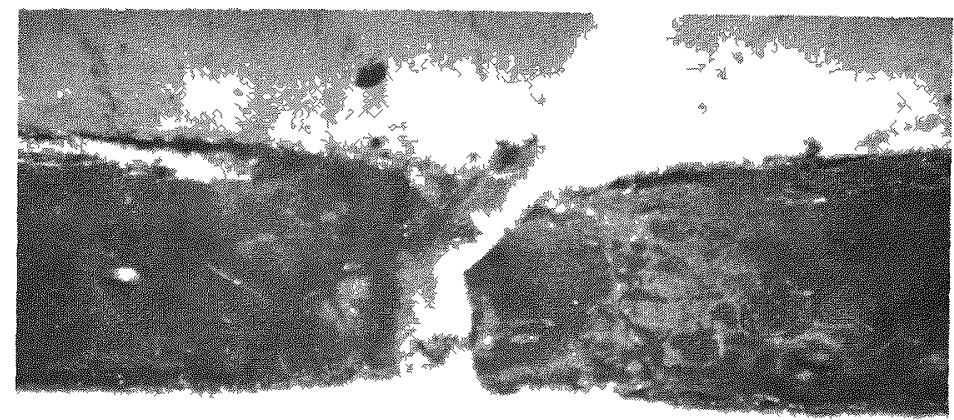

$4 \mathrm{X}$

HC10057

Flat

FIGURE A-21. FRACTURE ZONE AND MICROSTRUCTURE OF SPECIMEN ST -5-L AFTER TESTING AT $750 \mathrm{~F}$ This specimen was annealed at $1000 \mathrm{~F}$ for $1 \mathrm{hr}$ before testing. 

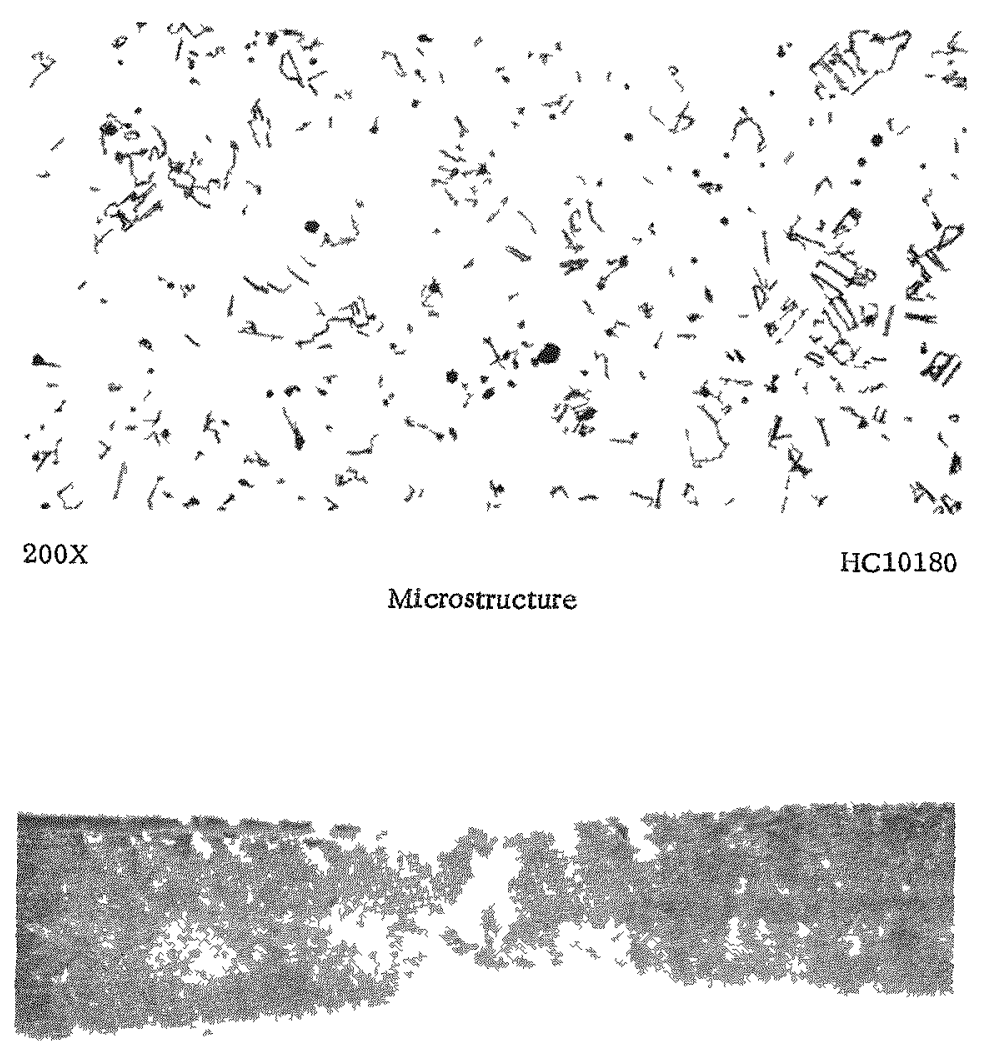

$4 \mathrm{X}$

HC10102

Edge

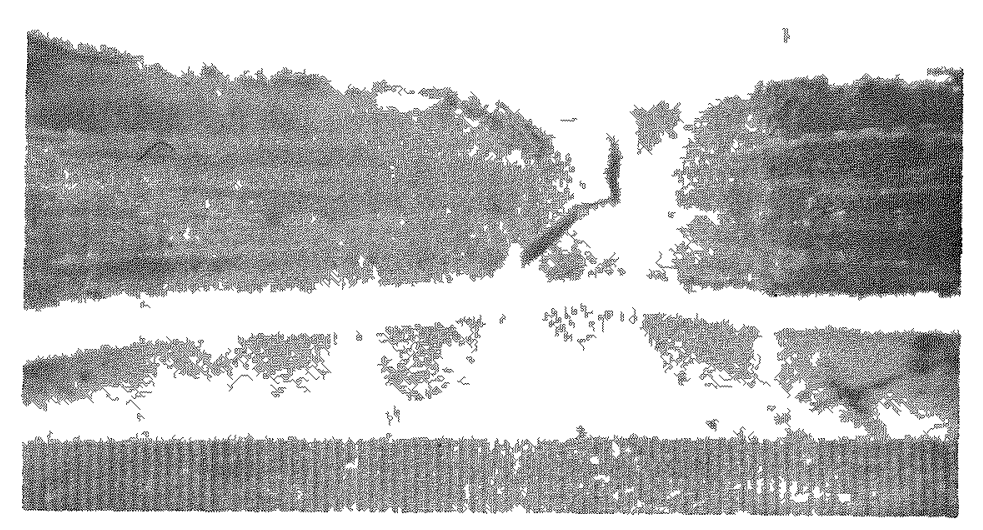

$4 \mathrm{X}$

HC10103

Flat

FIGURE A -22. FRACTURE ZONE AND MICROSTRUCTURE OF SPECIMEN ST-4-I AFTER TESTING A T 75 F This specimen was annealed at $1000 \mathrm{~F}$ for $1 \mathrm{hr}$ before testing. 


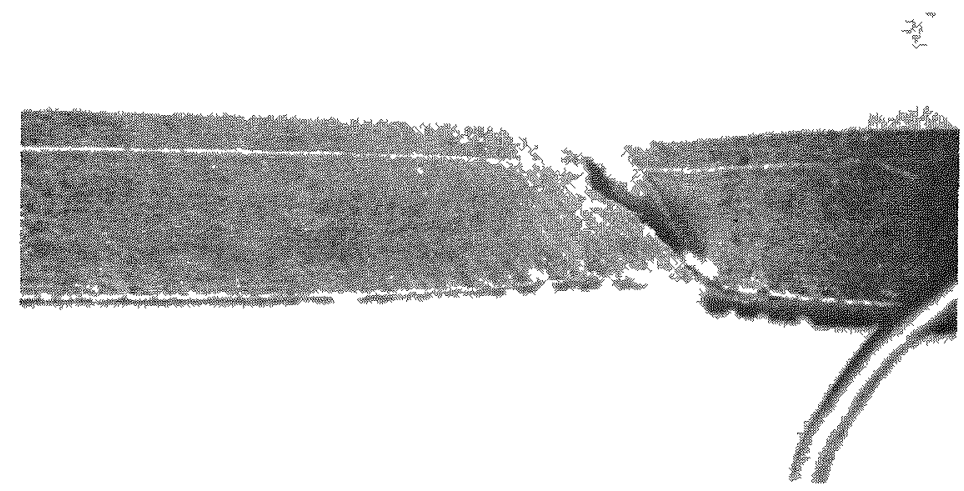

$4 \mathrm{X}$

HC10108

Edge

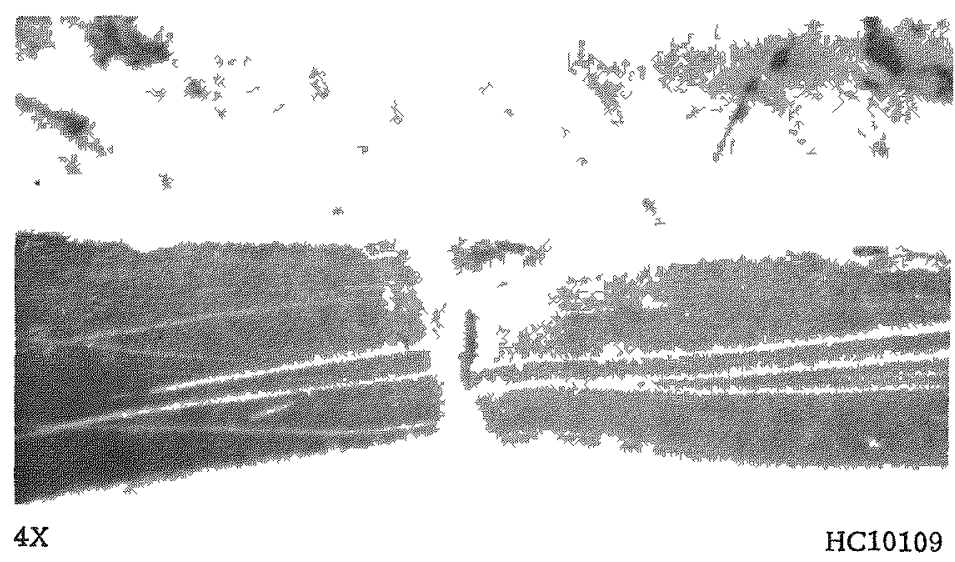

Flat

FIGURE A-23. FRACTURE ZONE OF SPECIMEN SB-4-H AFTER TESTING AT 75 F This specimen was annealed at $1000 \mathrm{~F}$ for $1 \mathrm{hr}$ before testing. 

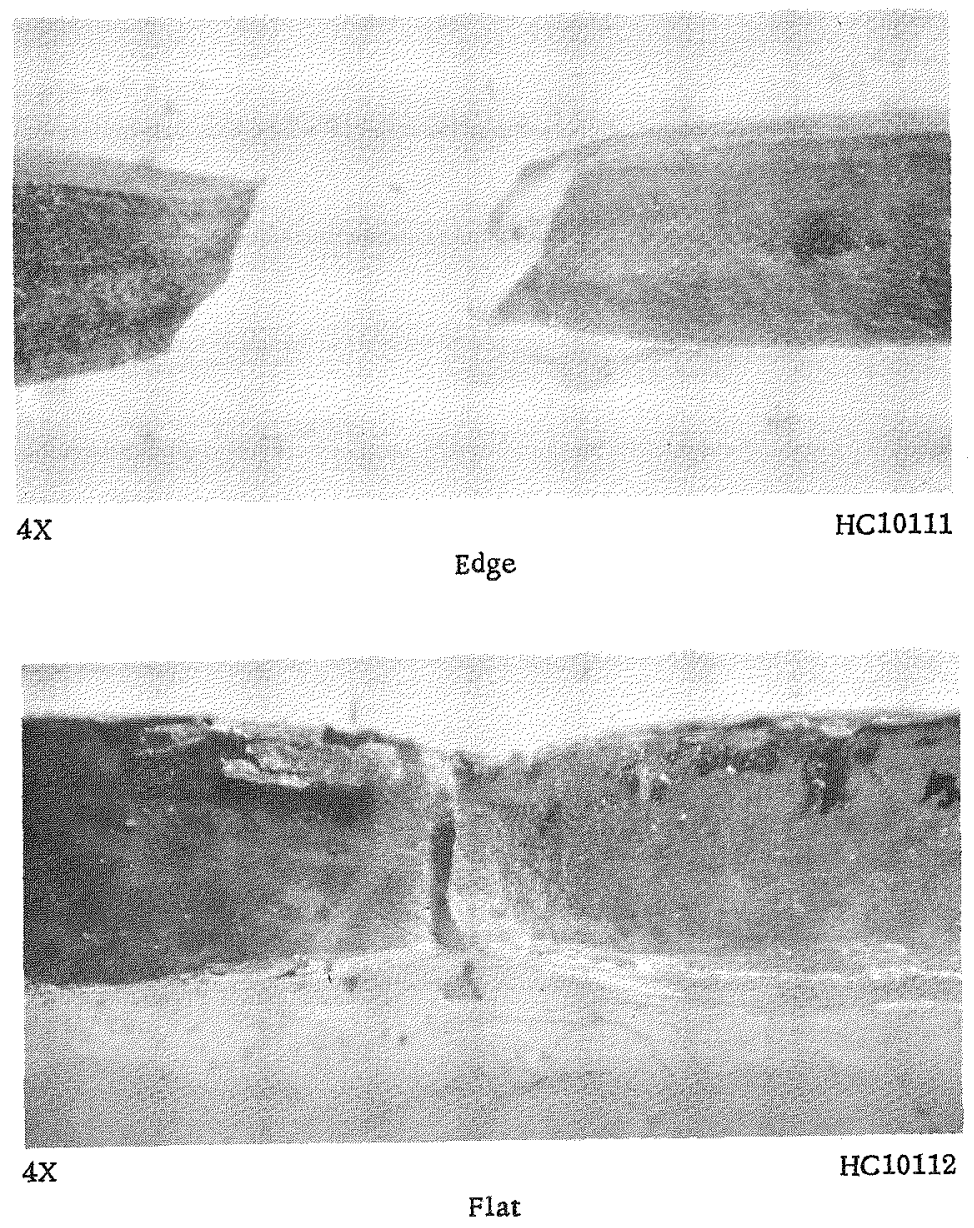

FIGURE A-24. FRACTURE ZONE OF SPECIMEN ST -3-H AFTER TESTING AT $750 \mathrm{~F}$ This specimen was annealed at $1000 \mathrm{~F}$ for $1 \mathrm{hr}$ before the test. 